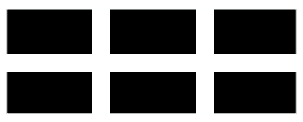

ThE WiLliam DAVIDSON INSTITUTE AT THE UNIVERSITY OF MICHIGAN BUSINESS SCHOOL

Organizational Culture and Effectiveness:

Can American Theory Be Applied in Russia?

\author{
By: Carl F. Fey and Daniel R. Denison
}

William Davidson Institute Working Paper Number 598

July 2003 


\title{
ORGANIZATIONAL CULTURE AND EFFECTIVENESS: CAN AMERICAN THEORY BE APPLIED IN RUSSIA?
}

\author{
Carl F. Fey \\ Stockholm School of Economics \\ P.O. Box 6501 \\ S-11383 Stockholm, Sweden \\ Tel. (46-8)-736-9450 \\ Fax. (46-8)-31-9927 \\ E-mail: carl.fey@hhs.se \\ and \\ Stockholm School of Economics in Saint Petersburg \\ Daniel R. Denison \\ International Institute for Management Development \\ Chemin de Bellerive 23 \\ Lausanne, Switzerland CH-1001 \\ Tel (41.21.618.0311) \\ E-mail: denison@imd.ch
}

May 2003

Forthcoming in Organization Science

The authors would like to thank the William Davidson Institute at the University of Michigan, the Ruben Rausing Foundation, The Institute of International Business at Stockholm School of Economics, and IMD for their financial support of this project. We would also like to thank participants of the IIB seminar series, the Nordic Workshop on International Business, as well as Stephanie Haaland, Marion Fey, Marina Libo, Natasha Libo, Pontus Engström, Johan Simonsson, and the firms who participated in this study. Finally, we would like to thank three anonymous Organization Science reviewers and especially Associate Editor-in-Chief Alan Meyer for help improving this paper. 


\title{
ORGANIZATIONAL CULTURE AND EFFECTIVENESS: CAN AMERICAN THEORY BE APPLIED IN RUSSIA?
}

\begin{abstract}
This paper examines the link between organizational culture and effectiveness for foreign-owned firms operating in Russia. Beginning with a model of organizational culture developed in the USA, the paper presents a multi-method analysis of culture and effectiveness in a transition economy. We argue that effectiveness in Russia relies more on adaptability and flexibility than in the USA. Furthermore, the legacy of the communist era forces firms in Russia to deal with a workforce with a unique time perspective and a unique set of sub-cultures that often undermine attempts at coordination and integration. We first explore these ideas using survey data on 179 foreign-owned firms operating in Russia and compare the results to those obtained for firms in the USA. We then present four case studies designed to ground the results in the Russian context, and to document cultural dynamics not captured by the model.
\end{abstract}

\section{KEY WORDS}

Organizational Culture

Effectiveness

Russia

Transition Economies

\section{JEL CATEGORIES}

M14, M12 
Many organizational researchers have examined corporate culture as a source of competitive advantage (Barney, 1986; Ott, 1989; Pfeffer, 1994; Wilkins and Ouchi, 1983), but explicit theories are few and empirical evidence is limited (Denison and Mishra, 1995). The theories that do exist (Denison, 1990; Kotter and Heskett, 1992; O’Reilly, 1989) have been developed and applied only in the USA. Scholars focusing on the applicability of American management theories abroad (Adler, 1991; Boyacigiller and Adler, 1991; Hofstede, 1980a; 1993; Lammers and Hickson, 1979) have asked, "Is organization science, as it is currently conceived, applicable across countries?" and "To what extent must organizational theorizing be modified due to national differences?" (Boyacigiller et al., 2003: 17).

This paper contributes to the ongoing debate by presenting a study of organizational culture and effectiveness that focuses on a set of foreign-owned firms operating in Russia. The study also compares the Russian results to results previously obtained in the USA. Russia merits study for several reasons. Russia is the largest country in the world in terms of territory, it has the $6^{\text {th }}$ largest population, and the $14^{\text {th }}$ largest GDP (World Bank, 2001). The legacy of Russia and the USA as cold war superpowers gives Russia special importance to global stability. Furthermore, since foreign investment is critically important to Russia's success as a key transition economy (Denison, 2001; Lawrence and Vlachoutsicos, 1990), the cultural problems encountered by foreign firms doing business in Russia (Elenkov, 1998; Fey, 1995; Fey and Beamish, 2001; Kvint, 1994) seem particularly important to address.

Our paper begins with an overview of the Russian context and its influence on organizational culture. Next, we introduce the model of organizational culture underlying this study and use this model to develop a set of research questions. We then present quantitative findings on the linkage between organizational culture and effectiveness based on data from 179 foreign-owned firms operating in Russia, and compare these findings to results from the USA. This quantitative analysis is followed by four qualitative case studies, designed to ground the quantitative results in the Russian context and to help examine several significant cultural dynamics that were not fully represented in the model.

\section{THE RUSSIAN CONTEXT}

Russia has a well-educated, low-cost labor force and is rich in natural resources. But Russia has not reached its economic potential during its transition to a market economy, partly because few outsiders appear to understand how to operate there. Russia has been plagued by problems such as 
organized crime, intractable bureaucracy, and an unstable political and economic system. Foreign firms have increased interest in Russia, but they often encounter cultural problems (Cattaneo, 1992; Fey, 1995). Shekshnia (1998) also suggests that organizational culture is a key determinant of success. As Luthans, Welsh, and Rosenkratz (1993: 742) noted, "The assumptions... are that the Russians are failing badly because they know little about modern management techniques and, in fact, US and Russian management systems are quite different. The time has come to assess these assumptions." Thus, we begin by reviewing the Russian management literature in areas closely related to organizational culture: management practices, work values, and national culture.

Russian Management Practices. Historically, Russian decision- making has been very centralized with little empowerment. This pattern was primarily imposed from the top but to some degree was also encouraged from below. Since Russian managers have traditionally been punished for negative results, even those beyond their control, they tend to exhibit learned helplessness (Kets de Vries, 2000) and a strong desire to want someone else to make decisions. To counter this ingrained problem, it is necessary to create a system of involvement in which employees are rewarded for taking initiative and held accountable for their actions, but not punished for unpredictable outcomes (Puffer and Shekshnia, 1996). Other authors (Lawrence and Vlachoutsicos, 1993; May, Bormann-Young, and Ledgerwood, 1998) also stress the importance of accountability. In Russia, being able to blame someone else is often regarded as tantamount to solving a problem. HRM practices typically reflect and reinforce national culture and organizational culture. One study of 66 Russian managers at the Tver Cotton Mill found that extrinsic rewards and behavioral management increased worker performance but that participative techniques resulted in decreased performance (Luthans, Welsch, and Rosenkratz, 1993; Welsch, Luthans, and Sommer, 1993). Puffer and Shekshnia (1996) argue that individual bonuses should be tied to initiative and personal accountability and that firms should organize social events and other group activities with workers, provide small-group incentives, and provide a mix of short and long-term incentives. Fey, Engstrom, and Bjorkman (1999) also stress the benefits of using bonuses in Russia. Russians also appear to be highly motivated by development opportunities (Fey and Bjorkman, 2001; May, Bormann, Young, and Ledgerwood, 1998; Shekshnia, 1998). For example, a recent study by Fey and Bjorkman (2001) showed that training is highly valued and is linked to firm performance. These HRM practices reflect important cultural values regarding empowerment and accountability. 
Another recurring theme in the management literature is the poor flow of information. As Vlachoutsicos and Lawrence (1990) have noted, Russian organizations often have good vertical flow of information, but poor horizontal flow from department to department. Information is typically seen as power, creating barriers to coordination and integration. Several authors have advocated using teams to achieve coordination since Russians like working in groups and are good at doing it (Puffer, 1992; Puffer, McCarthy, and Zhuplev, 1998; Vlachoutsicos, 2001).

Russian Work Values and National Culture. Organizational cultures are embedded in and shaped by national cultures. Puffer underscores several differences between Russian and US business ethics (Puffer and McCarthy, 1995), noting that giving bribes and ignoring senseless rules are more acceptable in Russia than in the USA, while blowing the whistle on fellow workers, having large salary differentials, and laying off people are more acceptable in the USA than they would be in Russia. Other authors (Holt, Ralston, and Terpstra, 1994; Ralston, Holt, Terpstra, and Cheng, 1997) have noted that Russian managers, compared to their American counterparts, value power more, need gratification less, and place lower value on tradition and higher value on security and stability. Russians are also said to be less individualistic and less open to change. Elenkov (1997) compared Russia to the USA on Hofstede's (1980b) four dimensions of national culture. The table below compares Elenkov's results for Russia to Hofstede's (1980) results for the USA.

\section{Elenkov (1997) Hofstede (1980b)}

\begin{tabular}{lcc} 
& Russia & USA \\
\cline { 2 - 3 } Individualism & 40 & 91 \\
Uncertainty Avoidance & 87 & 46 \\
Masculinity & 50 & 62 \\
Power Distance & 89 & 40
\end{tabular}

These results show that Russians are group oriented (Vlachoutsicos, 2001) and prefer to avoid uncertainty. Both might be expected given the social security imprinted by the Communist system and the surprises dealt to Russia in the past. Russians report medium masculinity and appear to have a fairly high power distance (the extent to which a society accepts that power in institutions and organizations is distributed unequally), reflecting the large social gap that exists between 
workers and managers in Russia. Further understanding of Russian character is offered by the famous $19^{\text {th }}$ century Russian historian Kliuchevskii (1990). He describes a set of stereotypical Russian behaviors including resourcefulness, patience under adversity, deprivation, and spurts of energy, combined with a tendency to dissemble and an inconsistency in seeing things through. He also describes Russians as circumspect, cautious, and ambiguous with a preference to look back instead of forward. Finally, he argues that Russians prefer to work in groups and to monitor results rather than set goals.

Although there is no specific Russian management literature on organizational culture and effectiveness, this review of the literature on management practices, values, and national culture highlights several important issues: the cultures of Russian organizations exhibit a unique set of issues concerned with involvement, empowerment, and accountability, as well as a serious set of issues with respect to achieving coordination and strategic direction as Russians adapt to the emerging market economy. These issues are reflected in the approach to culture taken in our study.

\section{ORGANIZATIONAL CULTURE AND EFFECTIVENESS}

A number of scholars have developed integrative frameworks of organizational culture (Allaire and Firsirotu, 1984; Hatch, 1993; Martin, 1992; Ott, 1989; Schein, 1985, 1990), but little consensus exists with regard to a general theory. Since culture is a complex phenomenon, ranging from underlying beliefs and assumptions to visible structures and practices, some observers question whether culture can actually be "measured" in a comparative sense. Research on the link between organizational culture and effectiveness is also limited by lack of agreement about the appropriate measures of effectiveness.

The current literature has its roots in the early 1980s. Deal and Kennedy (1982) and Peters and Waterman (1982) focused attention on the strategic importance of organizational culture and stimulated interest in the topic. Kotter and Heskett (1992) expanded on this by exploring the importance of adaptability and the fit between an organization and its environment. This paper builds on the framework developed by Denison and his colleagues (Denison, 1984, 1990, 1996; Denison and Mishra, 1995, 1998; Denison and Neale, 1996; Denison, Cho, and Young, 2002). This stream of research has developed an explicit model of organizational culture and effectiveness and a validated method of measurement. This model is based on four cultural traits of effective organizations, which are described briefly below with references to their grounding in the organizational studies literature. 
Involvement. Effective organizations empower people, organize around teams, and develop human capability (Becker, 1964; Lawler, 1996; Likert, 1961). Executives, managers, and employees are committed and feel a strong sense of ownership. People at all levels feel that they have input into decisions that will affect their work and see a direct connection to the goals of the organization (Katzenbach, 1993; Spreitzer, 1995).

Consistency. Effective organizations tend to have "strong" cultures that are highly consistent, well coordinated, and well integrated (Davenport, 1993; Saffold, 1988). Behavioral norms are rooted in core values, and leaders and followers are able to reach agreement even with diverse points of view (Block, 1991). Consistency is a source of stability and internal integration resulting from a common mindset (Senge, 1990).

Adaptability. Ironically, organizations that are well integrated are often the least responsive (Kanter, 1983). Internal integration and external adaptation can often be at odds. Adaptable organizations are driven by their customers, take risks and learn from their mistakes, and have capability and experience at creating change (Nadler, 1998; Senge, 1990; Stalk, 1988).

Mission. Effective organizations have a clear sense of purpose and direction defining goals and strategic objectives and expressing a vision of the future (Mintzberg, 1987, 1994; Ohmae, 1982; Hamel \& Prahalad, 1994). When an organization's underlying mission changes, changes also occur in other aspects of the organization's culture.

Applying this framework to top executives in 764 organizations, Denison and Mishra (1995) showed that four different cultural traits were related to several criteria of effectiveness. This research found that profitability was most highly correlated with the traits of mission and consistency. In contrast, innovation was most highly associated with the traits of involvement and adaptability, and sales growth was most highly associated with the traits of adaptability and mission. Like many contemporary models of organizational effectiveness, this model focuses on the contradictions involved in simultaneously achieving internal integration and external adaptation (Hatch, 1993; Schein, 1990). For example, organizations that are market-focused and opportunistic often have problems with internal integration. On the other hand, organizations that are wellintegrated and over-controlled usually have a hard time adapting to their environments. Organizations with a top-down vision often find it difficult to focus on the empowerment and the "bottom-up" dynamics needed for alignment. At the same time, organizations fostering broad participation often have difficulty establishing direction. Effective organizations are those that are able to resolve these contradictions without relying on simple trade-offs.

At the core of this model are underlying beliefs and assumptions. These "deeper" levels of organizational culture are typically difficult to measure and harder to generalize about. However, 
these underlying beliefs and assumptions result in organizational practices which are observable and which are represented by the four key traits of involvement, consistency, adaptability, and mission presented in Figure 1. This model incorporates many of the concepts identified in our review of the Russian management literature and thus serves as a useful framework for our study.

[Insert Figure 1 about here]

This study took a unique approach to applying this model in the Russian context. The model was used as a framework to test the idea that organizational culture influences effectiveness, but the model was also used as a reference point for understanding aspects of the culture of Russian organizations that may not have been well represented in the model. The first part of this study presents a quantitative test of the model examining the relationship between culture and effectiveness. The second part of this study then presents four case studies to ground the concepts.

In contrast to the typical approach of qualitative theory building followed by quantitative theory testing, the two parts of this study were conducted in tandem. As such, this study took several risks. For example, if the quantitative study had not supported the usefulness of the model for understanding culture and effectiveness in the Russian context, then it would have made little sense to use the model as a framework for the qualitative research. Using two approaches simultaneously allowed us to go back and forth between them to gain a better understanding of what was "behind the numbers" and to develop a better picture of areas where the concepts had a different meaning in Russia than in the USA.

\section{RESEARCH QUESTIONS}

The research questions guiding this investigation concern the applicability of the model in Russia, differences in the link between culture and effectiveness in Russia and the USA, and the underlying meaning and applicability of these concepts in Russia. The first two questions are examined through a quantitative study of 179 firms, and the third research question through four qualitative case studies.

As noted earlier, there is good support in the literature for the importance of the four cultural traits in the model. However, these findings are based upon samples of firms in the USA. Since many authors have suggested that national culture is likely to influence the way management theory "works" outside of the USA (e.g., Adler, 1991; Boyacigiller et al., 2003; Boyacigiller and Adler, 
1991; Hofstede, 1993; Hofstede, 1980a, 1980b), we first need to determine if a link exists between the four traits and effectiveness in Russia.

Research Question \#1: To what extent are involvement, consistency, adaptability, and mission associated with the effectiveness of firms in Russia?

Past research has shown that different cultural traits are related to different criteria of effectiveness (Denison and Mishra, 1995; Cameron and Whetten, 1983; Pennings, 1976). However, differences in national culture may influence the specific impact that the four traits have in Russia. Since the US is more individualistic, but Russians dislike uncertainty more and have greater power distance (Hofstede 1980a; Elenkov 1997), we might expect that involvement would be more important in the Russian context. In addition, since the beginning of Perestroika in 1987, the business environment in Russia has been turbulent and unpredictable (Holt, Ralston, and Terpstra, 1994; Puffer, McCarthy, and Zhuplev, 1998). As a result, adaptability is likely to be particularly important for firms operating in Russia. In contrast, mission and consistency, which are likely to be more important in a stable country like the USA, may be less important in Russia.

Research Question \#2: What is the specific pattern between the four traits and various criteria of effectiveness in Russia? How does the pattern in Russia differ from the pattern in the USA? Do the traits of adaptability and involvement have a stronger impact in Russia than they do in the USA?

Even if the first two research questions receive good quantitative support from the comparative study, numbers cannot tell the whole story. This is particularly true in cross-cultural research. For example, in the USA when someone nods his or her head up and down, it means "yes". However, the same action in Bulgaria means "no." The same action has exactly the opposite meaning in the two countries! Our case studies are used to address three main issues: First, they point out patterns of behaviors that reflect the concepts in the model and resemble patterns observed in the USA. Second, we use the case studies to describe patterns of behavior that fit with the concepts but are very different from patterns in the USA. Third, our case studies help us to highlight some of the underlying dynamics that help to explain these differences. These qualitative case studies help point out areas where the concepts in the model travel fairly well, but also identify specific patterns of behavior and underlying dynamics that may be quite different in Russia. Thus, our third research question takes a look at what is behind the numbers.

Research Question \#3: What are the patterns of behavior that illustrate the concepts in the model in Russia? Which patterns of behavior are similar to those that might be observed in the USA? Which patterns of behavior are different from those that might be observed in the 


\section{USA? What are some of the underlying forces that drive these different patterns of} behavior?

These three research questions are examined using two linked studies: The first two questions are examined in a comparative study of 179 firms, while the third question is examined through a set of four case studies.

\section{TESTING THE MODEL: A COMPARATIVE STUDY}

This section of the paper presents the quantitative results from a survey of 179 foreign firms operating in Russia. This first part of the research examines the impact of organizational culture on effectiveness in Russia and then compares those results to similar results from a sample of firms from the USA.

\section{Methodology}

The population for this study included all foreign firms operating in Russia in October 1997 with a parent firm headquartered in Canada, Germany, Finland, France, Sweden, or the USA. We combined lists of firms from each country's embassy for a total of 789 firms. 478 of the firms met our criteria of having at least 15 employees in Russia, operating before June 1995, and being located in Moscow or St. Petersburg. We chose to focus on foreign-owned firms for several reasons: Foreign-owned firms in many ways serve as a "bridge" between local and global firms. If the model does not apply to foreign-owned firms, it seems unlikely that it would apply to indigenous firms. Foreign-owned firms also tend to experiment more as they try to find a way to survive and prosper. Finally, the success of foreign-owned firms is necessary to ensure the continued investment of foreign capital.

Data collection occurred between October 1997 and January 1998. After calling to confirm that the company met the sampling criteria, we personally delivered a questionnaire to the firm for a senior manager to complete. Whenever possible, the researcher described the project and had the manager complete the questionnaire at that time. However, sometimes the manager opted to complete the questionnaire later and return it by fax. If questionnaires were not received within one week, we began a follow-up procedure including three telephone calls, faxing another questionnaire, and a fourth telephone call as a final reminder. Companies whose questionnaires had not been returned by the end of this procedure were considered non-respondents.

This procedure yielded 179 usable questionnaires completed by a senior manager in each firm, for a $37 \%$ response rate. Respondents were either general managers or deputy general 
mangers $(80 \%)$ or human resource mangers $(20 \%) .122$ were Russian and 57 were foreign. Position of the respondent was initially included in the regression equations but proved nonsignificant and was dropped from subsequent analyses to preserve degrees of freedom. We confirmed that the mean size of responding firms was virtually identical to the population mean for foreign subsidiaries in Russia ${ }^{1}$ (Goskomstat, 1998). Using a single respondent to depict a firm's culture has several limitations. It would, of course, be much better to have a large sample of respondents from each firm or in-depth case studies of each of the 179 firms. However, that would require a huge investment of resources. Because of the comparative focus of the first part of this study, we opted for the approach that would result in as large a sample of firms as possible. Single respondent studies are also quite common in the recent organizational and strategy literature (e.g., Birkinshaw, Hood, and Johnson, 1998; Delaney and Huselid, 1996; Delery and Doty, 1996; Denison and Mishra, 1995; Geringer and Hebert, 1989; Lee and Beamish, 1995; Shaw, Delery, Jenkins, and Gupta, 1998). A comparative citation analysis shows that single-respondent studies published in top journals are cited frequently ${ }^{2}$, suggesting that when properly executed, their results are accepted.

Some readers may also be concerned that gathering data from a single executive respondent may lead to common method bias. However, using a similar set of measures, Denison and Mishra (1995) showed that culture measures correlated more highly with objectively measured effectiveness than with perceptual measures of effectiveness. Given the well-known dominance of most directors of firms in Russia, we would also argue that it is more accurate to use the general director or deputy general director as a sole respondent in Russia than it might be in other countries. In any case, Fey (1997) has shown that respondents in different parts and levels of an organization tend to have similar assessments of an organization's culture.

Survey items drawn from the Denison Organizational Culture Survey (Denison and Mishra, 1995; Denison and Neale, 1996; Denison, Cho, and Young, 2002) and were translated into Russian and back into English, checked by Russian experts, and pilot tested. The four traits in the model each have three indexes that are the mean of three five-point Likert scale questions ranging from 1-5 (strongly disagree to strongly agree). Appendix A includes a complete list of all these items.

Following Denison and Mishra (1995), effectiveness was measured using seven five-point Likert items, ranging from $1=$ poor to $5=$ excellent. These items included overall performance ${ }^{3}$, market share, sales growth, profitability, employee satisfaction, quality of products and services, and new product development. These six specific effectiveness measures yielded a one-factor solution 
which we labeled the effectiveness index $(\mathrm{alpha}=.84)$. While some scholars have criticized the use of subjective measures of effectiveness, we found them useful for several reasons. First, since Russian accounting standards are still emerging, it is nearly impossible to obtain comparable financial data. Second, since firms operating in Russia have such diverse goals, comparing their short-term financial performance makes little sense. Third, virtually no centrally collected financial information is available. Finally, Russians are often secretive and unwilling to share financial information. Thus, in Russia the benefits of using subjective measures far outweigh the drawbacks. Furthermore, there is good precedent for using perceptual measures (Delaney and Huselid, 1996; Denison and Mishra, 1995), and prior research has shown that subjective measures of performance correlate well with objective measures of performance (Powell, 1992).

We also included control variables for size, industry, firm age, country of origin, and nationality of the respondent. We measured firm size as the number of employees and controlled for concentration in manufacturing. Firm age has little variance since foreign firms were not allowed into Russia prior to 1987. We also controlled for industry, using six the SIC-based categories prevalent in our sample:

1. Electrical, industrial, and precision instrument manufacturing

2. Wood, paper, textiles, food, and metal manufacturing

3. All other manufacturing

4. Banking, insurance, real estate, advertising, and accounting

5. Wholesale and retail trade

6. Other services

Finally, we included dummy variables to control for the influence of the home country of the parent firm and to separate Russian and non-Russian respondents. The US comparison sample used in this study comes from Denison, Cho, and Young (2002) and includes 36,542 respondents from 94 firms from the USA. For this sample there are $\geq 25$ respondents from each firm. Responses were aggregated at the firm level before conducting the analyses. Intra-organizational response rates ranged from $48 \%$ to $100 \%$. Surveys were completed by a wide variety of respondents in the different organizations. The surveys were completed between 1997 and 1999 and cover a wide variety of industries. Tests for industry effects revealed no significant industry effects on the relationship between organizational culture and effectiveness and thus controls for industry were dropped to preserve degrees of freedom. 


\section{Results}

The validity of the Russian culture measures is supported by the factor analysis presented in Table 1. The data factor nicely into four dimensions with relatively low cross loadings and all of the Cronbach alphas are greater than .70. Thus, the factor analysis demonstrates good convergent and discriminant validity.

\section{[Insert Table 1 about here]}

Table 2 addresses the issues raised in Research Question 1, and offers support for the model. All four of the model's cultural traits are associated with perceptions of organizational effectiveness in the 179-firm Russian sample: 31 of 32 correlations among the various dimensions of organizational culture and effectiveness reached statistical significance. To compare US and Russian managers as proposed in Research Question 2, Table 2 reports correlations from a sample of 94 US firms (Denison, Cho, and Young, 2002). This comparison shows that all four cultural dimensions in the Russian data are less highly correlated with overall performance, employee satisfaction, quality, and product development, than was the case in the USA. On the other hand, in the Russian data the cultural traits correlate more highlywith market share, sales growth, profitability, and the effectiveness index.

In Russia, adaptability and involvement are the strongest correlates of the effectiveness index, overall performance, profitability, and product development; involvement and mission are the strongest correlates of market share, sales growth, employee satisfaction, and quality. This pattern contrasts with the US results which show that mission correlates most highly with five of eight effectiveness dimensions.

[Insert Table 2 about here]

A more definitive look at the relationship between organizational culture and effectiveness is provided by the regression results. Table 3 reports the Russian results. It shows that the control variables are insignificant, with two minor exceptions: (1) firms in the electrical, industrial, and instrument manufacturing sector are slightly less profitable, (2) larger firms tend to receive somewhat higher quality ratings. Table 3 shows that all of the culture traits except consistency are significant predictors of some aspect of effectiveness, providing substantial support for the firsIt research question. The results also support the idea that different aspects of culture are linked to different elements of effectiveness. For example, Table 3 shows that sales growth is most highly associated with mission and that profitability is most highly associated with adaptability. Finally, 
Table 3 shows that involvement is the most important dimension of organizational culture for firms whose primary goal is employee satisfaction. A correlation matrix of the variables used in the regression analyses is presented in Appendix B. ${ }^{4}$

\section{[Insert Tables 3 and 4 about here]}

Overall, adaptability and involvement seem to be the most important determinants of effectiveness in the Russian context. They account for 12 of the 15 significant relationships associated with effectiveness and are also the most significant in the effectiveness and overall performance models. These results contrast with the regression results for the US data which are presented in Table 4. In the USA mission is the organizational cultural trait most highly associated with effectiveness as it is significantly associated with five of the eight effectiveness measures. Involvement is also significantly associated with employee satisfaction and the overall effectiveness index. Thus, involvement appears to be important for creating an effective organization in both the USA and Russia. However, mission appears the most important trait in the relatively stable USA while in Russia's transition economy, adaptability is the more important factor. The observation that different organizational cultural traits are more important in the USA and Russia addresses Research Question 2.

These comparative results are quite encouraging. The culture measures achieved a high level of validity, showing that comparative cross-national research on culture and effectiveness is quite possible. The correlation and regression results show many important similarities to the results from prior research from the USA, but present one important difference: In Russia's turbulent transition economy, stability traits such as mission and consistency are less strongly associated with effectiveness than are the flexibility traits of involvement and adaptability. The results also make good intuitive sense and encourage us to turn our attention to what lies behind the numbers.

\section{TAKING A CLOSER LOOK: FOUR CASE STUDIES}

The quantitative part of this study shows that many of the concepts in the organizational culture model appear to have an impact in the Russian context. But even where the results appear to indicate a similar impact in the US and Russia, it could be a mistake to assume that the concepts have the same meaning in the Russian context as they do in the US environment. For example, empowerment may be important in both contexts, but empowerment may entail very different behaviors in the two contexts. Thus, the first objective of the case studies is to ground the model in 
the Russian context through more detailed description. The second objective is to highlight aspects of the cultures of these firms that have an important impact on effectiveness but are difficult to describe using only the concepts in the model. This section begins with a description of the case study methodology, followed by background descriptions of the four firms and a summary table. Next, we ground the concepts of the model in the reality of the cases. The final part of this section focuses on several key themes that emerged from the case studies that were not well represented in the model but help to provide a better understanding of culture and effectiveness in the Russian context.

\section{Case Study Methods}

We began by identifying a subset of the 179 firms that had at least 70 employees and had manufacturing and sales operations in Russia. To control for the national culture of the parent firm and to facilitate access, we identified 13 Swedish firms that met these criteria and selected four firms representing a range of effectiveness levels (Eisenhardt, 1989). We then conducted 10 interviews in each firm. In each case, we interviewed one expatriate (either the GM or Deputy GM) and conducted the remaining interviews with Russians. In each firm, we interviewed the GM, the HR Manager, two production employees, one production manager, one marketing employee, one marketing manager, one financial or accounting employee, one engineer, and one engineering manager. Sixty percent of the interviews were conducted in English and the rest in Russian with a translator present. The interviews were semi-structured, following Merton, Fiske, and Kendall's (1963) approach. The core questions focused on the following topics: the interviewee's background, the organization's values, the unique aspects of the organization's history, the sub-groups in the firm, the organization's management and business practices, and the link between the organization's culture and effectiveness. The purpose of these interviews was to understand the organization and the impact that it's culture had on effectiveness.

Two researchers were present at each interview. Both took notes independently and typed them up each night. Any inconsistencies were discussed and resolved. Researchers' impressions were kept separate from the interviewees' impressions, and all data were included in the write-ups even when not specifically requested in the interview guide (Yin, 1984; Eisenhardt, 1989). Interview notes from the two researchers were compared to highlight differences and produce a master set of interview notes. Next we followed the "memoing" process (Glaser, 1978), to record 
patterns that the researchers noted within each site and across sites to identify the matches between the empirical pattern and the predicted pattern (Yin, 1984).

Our presentation of the case studies begins with brief background descriptions of each firm. This is followed by a discussion of the cases in terms of the four traits defined by the model, illustrating them with examples from the cases. The final section focuses on several key themes that emerged from the case studies that were not well represented by the model but are important for understanding firms in Russia.

\section{Four Case Studies: General Background}

AGA. Headquartered in Stockholm, Sweden, AGA is one of the world's leading producers of industrial gas (e.g., oxygen, hydrogen, argon) with 1999 sales of US $\$ 1.76$ billion and over 10,000 employees in 40 countries. AGA has a matrix structure with three business areas (manufacturing industry, process industry, and health care industry) and country organizations.

AGA entered Russia in 1908. After an interruption during the 1917 revolution, AGA began supplying the Russian market via its Finnish subsidiaries in 1934. In 1999, AGA Russia employed over 350 people with a head office in Moscow, a sales office in St. Petersburg and factories in Kaliningrad and Moscow. AGA Moscow experienced financial losses in Russia in 1997 and 1998, but cut expenses in 1999 and thus made a small profit even though their prices are high and the industry has overcapacity.

In 1995, AGA Moscow invested US\$10 million in a plant with a capacity of 100 tons per day. The "new" factory was an old AGA factory from Finland that was disassembled, shipped to Russia, and then reassembled in Balashikha, just outside of Moscow. AGA Moscow also set up 20 distribution stations throughout Russia. The Moscow office in Balashikha is divided into the sales department, mainly made up of new personnel, and the production side, mostly comprised of workers from the acquired production facility.

Alfa Laval. Alfa Laval produces dairy equipment for separating milk and cream, as well as heat exchangers. It has 13,800 employees in 110 subsidiaries in 50 countries producing annual revenues of US\$1.8 billion. Alfa Laval acquired the Potok factory outside Moscow in 1993 and renovated it to create a modern-looking factory in 1996. Today, with 300 employees, the factory is somewhat too large for Alfa Laval Potok's current needs.

Alfa Laval Potok has 20 distributors in different regions of Russia. In Novosibirsk, Alfa Laval Potok has a successful distributor covering most of Siberia and accounting for 50 percent of the total Alfa Laval Potok heating revenues. Alfa Laval Potok had poor initial results and many challenges to overcome. However, it appears that Alfa Laval has adapted well to the Russian environment, making its first profit in 1999. Alfa Laval Potok was originally supposed to focus on producing separation equipment, but this market had overcapacity. As a result, Alfa Laval Potok switched the majority of its efforts to producing heat exchange equipment for district heating which was a more promising business. This move 
took courage on their part and shows a good ability to adapt to the Russian market. Alfa Laval's efforts to switch its focus to heat exchangers, trim excess personnel and assets, and aggressively pursue sales explain why it is now profitable.

AssiDoman. The Swedish firm AssiDoman is one of Europe's largest forest-product companies with 18,000 employees and sales of US $\$ 3$ billion, 60 percent from outside Sweden. AssiDoman is divided into 5 business areas: forestry, packaging, craft products, cartons, and barrier coating. It first entered Russia when it acquired 57 percent of the paperproducing company Segezhabumprom in Karilea. This company ran into serious problems, and AssiDoman has only recently managed to liquidate this investment.

Nonetheless, AssiDoman still saw opportunity in the Russian market and invested US\$25 million to open a new factory in St. Petersburg in 1997. This modern factory focuses on the production and sales of corrugated packaging in northwestern Russia. Russian native Dennis Belkovsky (Managing Director) and his Danish wife Malene Ratajczak (Finance and Administration Director) manage the plant with an enlightened management style. According to AssiDoman, the Russian market for corrugated cardboard is growing rapidly. Its factory, which covers $15,000 \mathrm{~m}^{2}$, is capable of producing 60 million $\mathrm{m}^{2}$ of cardboard per year when working three shifts. Currently, however, only one shift, with 80 employees is working.

Lift. Lift (a pseudonym) is a division of a large global firm that develops, produces, sells, and services elevators. The parent company has 200,000 people, sales of US $\$ 22$ billion, and is organized in a matrix structure with national companies in one dimension and 30 business areas in the other dimension. Lift Moscow is a joint venture formed in 1994. Lift owns $80 \%$ of Lift Moscow and the Moscow Mechanical Complex , the remaining 20\%. In practice, Lift Moscow functions like a wholly owned subsidiary. Lift Moscow was supposed to be Lift's golden door to Russia, but its potential has not been reached since it has been unable to sell many elevators. Fortunately, it has been able to adapt by cutting the work force from 550 to 350 employees and by aggressively pursuing service contracts.

Since Lift Moscow produces only small elevators designed for residential use, local governments, who have limited resources, are their primary customers. Lift has had great difficulty selling elevators for cash and has resorted to barter. For example, in one recent deal, Lift "sold" a US\$1.2 million elevator system to a town. The town paid for the system by bartering US $\$ 1.15$ million in electricity to a pulp and paper company, that bartered US\$1.1 million in paper to a trading company that paid Lift US\$1 million cash. Many foreign firms refuse to consider barter deals even though they can be an effective way of doing business in Russia. Indeed, barter deals have several drawbacks -- they take much longer and require a $20 \%$ mark-up to be profitable. However, they allow firms to make sales that would not otherwise be possible. The use of barter deals and the focus on service are two key examples of how Lift has adapted.

\section{Grounding the Model in the Russian Context}

To summarize the case studies, we present several ratings of the culture and effectiveness measures. The researchers' assessments, the survey evaluation of the GM, and the survey 
evaluation of the ten interviewees are all presented in Table 5. These results show that the different assessments are quite consistent.

[Insert Table 5 about here]

Each of these cases provides examples that help ground the model in the Russian context. Some of the examples show direct similarities to firms in a Western context, while other examples appear to illustrate the general concepts outlined in the model, but show many differences from firms in the West. This section presents our qualitative findings.

Involvement. Several of the cases provide examples of involvement similar to what might be found in the West, while other examples provide a very different feel. For example, the AssiDoman production manager rewarded workers who could operate multiple machines and put a chart on the wall where workers could see how many machines they were certified to operate. Nonetheless, strong leaders who exert tight control are an enduring Russian tradition and the overall level of involvement seems quite a bit lower than would likely be the case in the West. For example, the same production manager who rewarded workers for mastering multiple machines exerted very tight control over workers and would not allow them to make personal calls home, even if they had a sick child. Workers also complained that management often made them clean their aging machinery over and over again when work was slow. Nonetheless, workers still appear to place high value on capability development. In this same organization, when workers were asked if they would prefer an extra month's pay or the chance to attend a one-week training course, most said that they would choose the training course. This is consistent with assertions that Russians may attach higher value to development than their counterparts in the West (Puffer, 1992).

Other examples of involvement appear to be more unique to Russia. Top management at Alfa Laval would often delegate decisions to middle management. However, because top management had an "open-door" policy, the middle managers would come back over and over again asking top management to "decide" on an issue that had officially been delegated to them. Top management would respond by asking for the pros and cons of different alternatives but, in the end, tried to make the middle managers decide. Top management thought that this was better than abruptly telling middle management that it was their job to decide. Over time the middle managers slowly learned to make decisions on delegated issues. Alfa Laval, in fact, was probably the best example of high involvement among the four case studies. 
AGA provides a useful example of how expectations of involvement and the sense of belonging to a team often follow functional lines. AGA had two very different subcultures. People in the top management, sales, and accounting departments were young, new to the firm, highly motivated, and open to trying new ways of working. People in the production department were older and had been working at the plant for many years. This second group of employees primarily wanted stable jobs with salaries they could live on and were not eager to change the way they had worked for years. Both groups were motivated by membership in their functional sub-groups but not by their membership in the organization as a whole. While this general phenomenon occurs in firms in the West, it was clearly more extreme in AGA. For example, the first time we interviewed two factory workers, we asked, "How does it feel to work for AGA?" They replied, "We don't work for AGA." Further questioning revealed that what they meant was that they worked for the Balashikha plant and regarded AGA as only an investor. The management/sales/accounting group viewed the production workers as ineffective employees that they inherited with the plant, many of whom wanted their salaries without having to work hard. However, the factory employees saw the management group's high salaries and fancy offices as a major problem that was preventing AGA from being profitable. "After all," one of the production workers commented, "the sales employees cost money, but they are not really producing anything."

Consistency. Several of the cases illustrate aspects of the cultural trait consistency that parallel observations made in firms in the West. The AGA and Alfa Laval cases reveal serious problems with coordination and integration stemming from the differing mindsets across functions and the poor communication between departments.

Coordination and communication problems are, of course, also common within firms in the West. However, the cases suggest that the scale and scope of these deficiencies are substantially greater in Russia. For example, we asked questions about each firm's core values. In Lift, several of the employees gave the same answer, "The core value of the firm is to maintain the formal system." Their response does point to a consistent set of core values, but shows that they think that the primary purpose of the firm is to maintain the integrity of the authority structure - not a response that an employee in the West would often give. Another example illustrating both the applicability of the general concept and the idiosyncrasy of its application in Russia came from AGA. When we asked one lower-level employee whether he agreed with management's decisions, he replied, "Right now, people really have no choice other than to agree." This comment shows the relevance of the 
general concept of alignment and consensus across levels, but also illustrates the different connotation attached to "agreeing" in Russia.

Adaptability. The case studies illustrate a number of aspects of adaptability. The data reflect certain dynamics similar to those in Western organizations, while others are quite different. AssiDoman's use of two-person sales teams provides an example paralleling what might be found in the West. To respond more quickly to customers, AssiDoman paired one salesperson on the road with another salesperson in the office. This assured that customers would be able to contact someone even when their sales representative was on the road. The pairing was also helpful in that the salesperson on the road could rely upon his or her partner in the office to make certain that orders were placed with the production department on a timely basis. Although one salesperson with a laptop and cell phone would probably do this job in the West, the example shows how a small team with shared responsibility can make the system respond more quickly to customers.

Other examples of adaptability that are more specific to the Russian context came from Alfa Laval and Lift. In an effort to survive, Alfa Laval quickly changed its focus from separation equipment to heat exchangers. In Lift, the original focus on producing and selling new elevators in Russia was expanded to also include servicing existing elevators. Servicing existing elevators became the main part of Lift's business. The few new elevators that Lift was able to "sell" were often arranged through barter. Drastic strategic changes of this sort may occur as a part of restructuring in the West, but in the Russian context they are clearly a more routine aspect of "business-as-usual." This underscores the importance of adaptability as a concept, even if it takes a different form in the Russian context. Russian firms' approaches to creating change are also instructive. On one hand, Russians appear to be able to endure change of almost any sort, sustained by their combination of resignation, fatalism, and ingenuity in the service of survival. On the other hand, their concept of a proactive approach to change in which individuals shape their own future appears quite limited. It is noteworthy that the most adaptable firm, AssiDoman, used an "open-tochange" mindset as a key criterion in the recruitment of new employees.

Mission. Because of the continuous state of turbulence in the Russian business environment, a clear sense of mission is difficult to establish. Thus, with few exceptions, the positive examples in our case studies had to do with the way that drastic organizational changes were communicated to employees. For example, the two least effective organizations, Lift and AGA, both changed direction quickly, but did little to communicate these changes to their employees. In Lift's case, the 
change from production, sales, and service to only service was not communicated throughout the organization. Changes were simply made on the operational level, and employees were expected to follow. In AGA's case, a series of unmet sales targets quickly changed its strategic goals from expansion to survival. But employees seemed largely unaware of the rationale for these changes. Two other cases, Alfa Laval and AssiDoman, illustrate the use of mission to foment change. In Alfa Laval, the strategic rationale for the shift from separation equipment to heat exchangers was well communicated and well understood throughout the firm. In AssiDoman, we saw one of the few examples of creating a proactive sense of mission. The subsidiary was led by a husband and wife team who made a deliberate attempt to create an organization that was, in their words, "a good place to work." Their success in communicating this mission was evident in a number of their employees' comments in interviews.

Our analysis of the data from these four case studies also supported the quantitative findings in another important way. Our informants provided many more examples of the impact of adaptability and involvement on a firm's effectiveness than of consistency and mission, which appeared to be far less powerful determinants of effectiveness in the Russian context. Comments relating to involvement and adaptability also contained many examples of creative solutions to problems posed by the Russian context. Our queries about consistency and mission elicited some interesting examples, but these cultural traits clearly are less salient in the turbulent Russian business environment. Thus, the results of the case studies mirror the quantitative findings.

\section{Understanding Organizational Culture in the Russian Context}

In the previous section, the qualitative results reported for each of the four traits fell into two different categories: a) qualitative findings that fit well with the concepts in the model and were illustrated through patterns similar to what one might encounter in the West, and b) qualitative findings that fit reasonably well with concepts in the model, but felt quite different from the patterns typically encountered in Western firms. This section of the paper takes this analysis one step further and focuses on several cultural dynamics that are not as well represented in the model and are quite different from the conditions typically encountered by Western firms.

First, it is important to acknowledge the influence of the Communist era on the culture of firms in Russia. Like firms in most transition economies, our case study firms were "functionally incomplete" (Newman and Nollen, 1998). During the Communist era, the functions of strategy, finance, sales, and marketing were primarily performed by the State. Thus, one of the major 
transitions has been to establish these functions at the firm level. From a cultural point of view, these changes often feel more like a merger or acquisition (of the new functions) than like crossfunctional differences in the West. They influence all aspects of firm operation that require crossfunctional coordination. Second, the tradition of central control and authority means that the salience of any conception of the firm or the value chain is weak or non-existent compared to the power of the functional boss. Russians often regard firm-level goals as distant and unfamiliar priorities compared to maintaining the integrity of one's functional area.

This pattern is clear in several of the cases. Indeed, one of our first impressions of AGA was of the co-existence of two separate worlds. The top management and the sales and accounting departments make up one world, while the manufacturing department makes up another. Most employees in the former group were young, ambitious, and new to the firm, while the second group was older and had worked at the factory for years. The first group was housed in a separate building that was much nicer than the factory building. Communication between the two groups was limited.

A similar picture comes from Alfa Laval. Several top managers were Swedish, with poor knowledge of Russian. They tended to work with younger English-speaking Russians. The language barrier created an "us" versus "them" feeling and undermined team spirit. "Us" referred to the people on the fourth floor, who speak good English, are new at the production plant, and perhaps worked at Alfa Laval's sales subsidiary prior to the acquisition of the factory. "Them" referred to the older managers from Potok with limited knowledge of English, located on the third floor.

One employee at the Potok plant told us about the difficulty he had understanding the Alfa Laval culture. Prior to Alfa Laval's acquisition of Potok, meetings were very formal with chairs assigned according to position. Now, Alfa Laval Potok employees are encouraged to work together as equals to try to solve problems. This is difficult for older managers. To them, communication between people of different levels is unnatural. To learn the new style, the old managers went to Sweden for a week to see the new management style in action. As one participant said, "I understood right then how work was to be done. It is like the old Russian proverb that says it is better to see something once than to hear it one hundred times." In Lift, we saw a picture of authority distribution that was more traditional in Russia. When we asked one manager if workers could suggest product modifications he answered, "You don't understand: Workers work; managers know everything." 
These examples illustrate a difficult challenge faced by firms in the Russia. Many firms, in effect, have two workforces. The first consists of older workers with a traditional Russian mindset who resist change. They are primarily found in production and engineering where there is no substitute for their technical expertise. The second workforce is made up of young, aggressive "New Russians" who are generally eager to adapt. Members of this group are driven by career ambitions and often have some training in business, English, or a few years experience working for a foreign firm in sales or marketing. It also appears to be a common pattern to place younger workers in charge of older ones early in their careers, adding to the tension.

The impacts of subcultures are well established in the organizational research literature (Hatch, 1993; Martin, 1992; Van Maanen and Barley, 1984), and provide one point of reference for understanding these dynamics. Indeed, one shortcoming of the culture model used here, like other general models (Hofstede, 1991; Kotter and Heskett, 1992), is that it can foster the impression that organizations have unitary cultures. Researchers using these approaches need to be aware of the subcultures that exist and the dynamics they create. Kliuchevskii's (1990: 58-64) comments on the Russian "tendency to dissemble," "preference for working in groups," and "circumspect nature" highlight elements of Russia's national culture that may help give rise to organizational subcultures.

Another example from AGA helped clarify the impact that these dynamics can have on effectiveness. When we visited the factory we noticed a bottleneck which seemed to be caused by operating only one forklift despite three others parked nearby. We learned that the forklifts had been purchased three months ago, but three of them had been idle for the last five weeks with broken sparkplugs. We traced this problem through the system: The operators said that they had informed their supervisors of the problem. The supervisors told us that they had reported the problem to the repair center. The repair center director told us that those sparkplugs were difficult to get in Russia and had been ordered from Germany. Each person felt that he had done his job and that there was nothing to do but wait for the sparkplugs to appear. While the workers were upset that they did not have three of their four forklifts, no one took the initiative to ensure that the sparkplugs would arrive faster. Further, no one seemed upset that a major investment in the forklifts was going to waste and that workers' time was being used inefficiently. In reality, a phone call to Germany probably could have had a box of sparkplugs delivered FedEx to Moscow in a few days. Top managers at AGA Russia were unaware of this problem and would have taken action if they had known. 
This example also points out the importance of the concept of time as a resource. In many Western firms, competitive strategies based on time are well established (Stalk, 1988). None of the case study firms viewed time in the same way as a well-managed firm in the West. The proclivity for responding only to central authority means that most Russian workers and managers place little value on responsiveness, the goals of the firm, the shared responsibility of employees, or the mechanisms by which unresolved problems are surfaced for managers to address. In contrast to the literature's treatment of differences in time perspective as a stable national characteristic (Bluedorn, 2000; Giddens, 1990, 1991; Hall, 1976; Hofstede, 1991; Trompenaars, 1998), we uncovered significant differences between the four firms, suggesting that individual firms have great latitude in the extent to which they reflect national tendencies. Our findings also suggest that a firm's concept of time may be influenced by its exposure to the West and by the level of competition in its industry.

The cultural dynamics described above are summarized in Figure 2. As the economic transition shifted the division of labor between the state and the firm, existing firms were rendered functionally incomplete. Adding the functions of management, finance, strategy, and marketing created an imbalance in the demographics of these firms and spawned subcultures with little shared sense of the firm as a whole. Within this context, coordination problems are widespread and their solution is essential for effective organizational performance. The problems of coordination across subcultures are influenced by several Russian national characteristics, particularly the tendency to dissemble and the concept of time as a resource. These intra-firm dynamics are also influenced by the changes taking place in the economic system that require firm-level economic transitions and by increasing levels of market-based competition. As noted earlier, the dynamics noted below in Figure 2 could have been explained simply by reference to the concepts in the organizational culture model. Indeed, consistency and coordination, empowerment, and the presence of a firm-level mission all could be discussed with reference to concepts in the model. But discussing the examples only in terms of the concepts in the model would miss the underlying pattern uncovered in the case studies and presented in Figure 2. This pattern is very useful in understanding the culture of organizations in Russia.

\section{[Insert Figure 2 about here]}

These four case studies have grounded our conceptual model in the realities of the Russian context and addressed the issues posed in our third research question. In general, the case studies support the idea that the model is a useful starting point for understanding issues of culture and 
effectiveness in the Russian context. Indeed, we could have discussed the dynamics highlighted in this section in terms of the model, but doing so would have missed the point that concepts can have different meanings in different contexts, even as they have wide applicability across those different contexts. The case studies highlight an interesting distinction between the behaviors that illustrate the concepts in the model and are similar to what one might observe in firms in the West and those behaviors that illustrate the concepts, but are very different from what one might observe in a firm in the West. This distinction is very helpful because it illustrates that the concepts may travel fairly well, helping to account for the quantitative support for the model, but that the specific patterns of behavior that exemplify the concepts may vary quite a bit across cultures. Indeed, this aspect of the study provides an interesting example of how a theory can provide a useful framework and point of reference for understanding cultural patterns that go far deeper than just the model.

\section{DISCUSSION}

This study has taken an American model of organization culture and effectiveness and applied it to understand the performance of a set of foreign-owned firms operating in Russia. Several clear substantive differences have emerged from this research. The first is the importance of flexibility in Russia. Adaptability proved to be the most useful dimension in the model for understanding overall effectiveness. This finding also makes good intuitive sense given Russia's turbulent and unpredictable environment. This stands in contrast to a more stable environment like the USA, where mission appears to take on a much greater importance. Involvement also appears to be important to effectiveness in Russia. Under communism, competition between groups was encouraged, but competition between individuals was discouraged. As a result, Russians like working in groups and are good at it (Vlachoutsicos, 2001).

Other substantive insights emerged from the case studies. These provided good support for the applicability of the model, but also focused our attention on issues specific to Russia. The most distinctive pattern that we observed was the combination of dynamics, summarized in Figure 2, that is driven by the "functionally incomplete" organizational structures inherited from the Communist era. These dynamics appear to be an important feature of the organizational cultures of firms operating in transition economies (Newman and Nollen, 1998). Future research on international management and cross-cultural differences should not neglect this important set of issues faced by managers in transition economies. 
This study speaks to several other issues in the organizational literature. First, this paper has made a modest contribution to the longstanding debate about the wisdom of using theories developed in one part of the world to understand organizational phenomena in other parts of the world (Adler, 1991; Boyacigiller and Adler, 1991; Boyacigiller et al., 2003). The paper provides an interesting point of reference in that debate. On one hand, this study illustrates that a model of organizational culture developed in the USA can be applied in the Russian context and can be useful for predicting differences in effectiveness. But in addition, the research shows that the model can be a useful foundation for understanding differences in the culture-effectiveness relationship across cultures. Differences between national contexts can often be clarified through comparative analysis. The use of a general model is helpful, if not essential, to the comparative process.

The novel combination of qualitative and quantitative methods used in this study will also be of interest to organizational researchers. The study began by using an existing model of organizational culture and effectiveness as a starting point for the research. The first part of the study presented a quantitative test of the model and showed that the model was useful in understanding effectiveness but that the results were somewhat different from the results for a sample of US firms. The quantitative results were used as probes to inform our research questions rather than tools to refute falsifiable hypotheses. The second part of the study selected four firms for in-depth qualitative analysis. These case studies generated a number of examples that served to ground the theoretical concepts in the realities of the Russian context. The case studies offered examples that fit well with the model, but also highlighted themes that were invaluable in understanding the realities of the Russian context but were not fully anticipated by the model.

In contrast to the typical approach of qualitative theory-building followed by quantitative theory-testing, this study pursued both methods at the same time and allowed us to move more quickly toward our goal of understanding the link between culture and effectiveness in the Russian context. As mentioned earlier, this approach carried several risks. Until we had established the validity of the model in the Russian context, it did not make much sense to plan to use it as a framework for interpreting the qualitative data. This meant that we were continuously comparing the findings from the two methods. For example, when we began to analyze our survey data we also continued analyzing our qualitative results to make certain that the model could be a useful frame of reference for interpreting the results from both studies. Had we done the qualitative study first we could not have explored the themes that emerged from the quantitative study to the same extent that 
we have here. Had we conducted the qualitative study second, we could not have understood if the model had validity and meaning in the Russian context. It is also worth noting that we use the quantitative data as a probe to inform our general research questions, rather than as a tool to refute falsifiable hypotheses. In other words we follow the logic of exploration, rather than the logic of verification.

When it became clear that the quantitative results supported the model, our focus changed. It then made sense to use the qualitative data for several different purposes. The first purpose was to help illustrate the concepts in the model and to ground the findings in the reality of Russian organizations. This step of qualitative elaboration worked quite well, and it helped us to see many interesting and unanticipated insights that were hiding behind our quantitative analyses. But the qualitative data also served a second purpose of describing examples that fit well with the concepts in the model but illustrated those concepts with behaviors, dynamics, and patterns that were quite different from what might be observed in a Western context. This taught us an important lesson: the model may be "valid" in the Russian context, but there may still be much to learn about what the constructs actually mean in that context.

This discovery also taught us a healthy respect for the linkage between theoretical concepts and the actual behavioral patterns that exemplify them. As Denison (1996) noted, the link between concepts and behavior can vary greatly among countries. He cited the example of the meaning attached to individuals wearing surgical masks on the streets of Tokyo and Los Angeles. In Tokyo, wearing a surgical mask was portrayed as a form of pro-social behavior by those who had a cold and wished to make certain that they did not transmit it to others. In Los Angeles, wearing a surgical mask was a means of protecting one's self from the dangers of the natural and social environment. The concepts of collectivism and self-interest are salient in both contexts, and the same behaviors existed in both contexts. The link between the two, however, is exactly the opposite.

In an effort to help explain the differences that we observed in effectiveness across organizations, the final stage of the qualitative analysis focused on the most distinctive cultural pattern that we observed, linking functional incompleteness, sub-cultures, time perspective, and coordination to help explain the differences that we observed in effectiveness. This pattern influences many of the concepts and measures in the model but reveals a far more fundamental dynamic than we could describe using any single dimension. Combining these insights enabled us 
to both validate the model and to provide a more complete understanding of the dynamics of organizational cultures in the Russian context.

\section{ENDNOTES}

1. To test for response bias we confirmed that the respondent firm size of 91 was almost identical to the population of foreign subsidiaries in Russia with more than 15 employees, which averaged 92 employees (Goskomstat, 1998).

2. We conducted a comparative citation analysis for a 1996 issue of Academy of Management Journal, 39(4), which included two single respondent studies; Delery and Doty, cited 75 times according to the social science citation index and Delaney and Huselid, cited 55 times. These single respondent studies compare positively to other studies in the same issue of Academy of Management Journal which are cited, on average only 21 times. Thus, scholars appear to see significant value in single-respondent studies.

3. It is interesting to note that when the six specific effectiveness measures are regressed on our general effectiveness measure (overall performance), we find that sales growth, profitability, quality of products and services, and employee satisfaction are the significant drivers of overall performance in the Russian data. New product development and market share have positive betas, but are not significant. In the case of the US data, the results are the same except that market share is also significant.

4. These results are also encouraging in that they show that correlated measurement error between the independent and dependent measures could not have accounted for all the significant results. If this were the case, we would expect to find all of the variance claimed by the first variable entered into the regression equation, thus leaving only one significant predictor. Since all of the equations have more than one significant predictor, this suggests that the results are quite robust. 


\section{REFERENCES}

Adler, N. J. (1991), International Dimensions of Organizational Behavior ( $2^{\text {nd }}$ ed.), Boston: Kent Publishing.

Allaire, Y. and M. Firsirotu (1984), “Theories of Organizational Culture," Organization Studies, 5, 193-226.

Barney, J. B. (1986), "Organizational Culture: Can it be a Source of Sustained Competitive Advantage?" Academy of Management Review, 11, 656-665.

Birkinshaw, J., N. Hood, and S. Jonsson (1998), "Building Firm-Specific Advantages in Multinational Corporations: The Role of Subsidiary Initiative," Strategic Management Journal, 19, 221-241.

Block, P. (1991), The Empowered Manager: Positive Political Skills at Work, San Francisco: Jossey-Bass.

Bluedorn, A. (2000), "Time and organizational culture," in N. Ashkenasy, C. Wilderom, and M. Peterson (Eds.), Handbook of organizational culture \& climate, Thousand Oaks, CA: Sage Publications, 131-146.

Boyacigiller, N.A. and N.J. Adler (1991), "The Parochial Dinosaur: Organizational Science in a Global Context," Academy of Management Review, 16, 2, 262-290.

Boyacigiller, N.A., M.J. Kleinberg, M.E. Phillips, and S.A. Sackmann (Forthcoming), "Conceptualizing Culture: Elucidating the Streams of Research in International CrossCultural Management," In B.J. Punnett and O. Shenkar, (Eds.), Handbook for International Management Research, Ann Arbor: University of Michigan Press.

Cameron, K., and D. Whetten (1983), Organizational Effectiveness: A Comparison of Multiple Models, New York: Academic Press.

Cattaneo, E. (1992), "Managing Joint Ventures in Russia: Can the Problems be Solved?" Long Range Planning, 25, 5, 68-72.

Davenport, T. (1993), Process Innovation: Reengineering Work Through Information Technology, Boston, MA: Harvard Business School Press.

Deal, T. E. and A. A. Kennedy (1982), Corporate Cultures: The Rites and Rituals of Corporate Life, Reading, MA: Addison-Wesley Publishing Co.

Delaney, J. T. and M. A. Huselid (1996), "The Impact of Human Resource Management Practices on Perceptions of Organizational Performance," Academy of Management Journal, 39, 949969.

Delery, J. and D. Doty (1996), “ Modes of Theorizing in Strategic Human Resource Management: Tests of Universalistic, Contingency, and Configurational Performance Predictions," Academy of Management Journal, 39, 4, 802-835. 
Denison, D. R. (1984), "Bringing Corporate Culture to the Bottom Line", Organizational Dynamics, 13, 2, 4-22.

Denison, D. R. (1990), Corporate Culture and Organizational Effectiveness, New York: Wiley.

Denison, D. R. (1996), "What IS the Difference Between Organizational Culture and Organizational Climate? A Native's Point of View on a Decade of Paradigm Wars," Academy of Management Review, 21, 3, 619-654.

Denison, D. (2001), Managing Organizational Change in Transition Economies, Mahway, NJ: Lawrence Erlbaum Associates.

Denison, D.R., H.J. Cho, and J.L. Young (2002), "Diagnosing Organizational Cultures: Validating a Model and Method," Working paper, International Institute for Management Development, Lausanne, Switzerland.

Denison, D. R. and A. K. Mishra (1995), "Toward a Theory of Organizational Culture and Effectiveness," Organization Science, 6, 2, 204-223.

Denison, D. R. and W.S. Neale (1996), Denison Organizational Culture Survey, Ann Arbor, MI: Aviat.

Eisenhardt, K. M. (1989), "Building Theories From Case Study Research,” Academy of Management Review, 4, 532-550.

Elenkov, D. S. (1997), "Differences and Similarities in Managerial Values Between U.S. and Russian Managers," International Studies of Management and Organization, 27, 1, 85-106.

Elenkov, D. S. (1998), “Can American Management Concepts Work in Russia: A Cross-Cultural Comparative Study," California Management Review, 40, 4, 133-155.

Fey, C. F. (1995), "Important Design Characteristics For Russian-Foreign Joint Ventures," European Management Journal, 13, 4, 405-415.

Fey, C.F. (1997), Organizational Climate Similarity and Performance: IJVs in Russia. Doctoral Dissertation, University of Western Ontario.

Fey, C.F. and P.W. Beamish (2001), "Organizational climate similarity and performance: International joint ventures in Russia," Organization Studies, 22, 5, 853-882.

Fey, C.F. and I. Björkman, (2001), “The effect of human resource management practices on MNC subsidiary performance in Russia," Journal of International Business Studies, 32, 1, 59-76.

Fey, C., Engström, P., and I. Björkman (1999), "Effective Human Resource Management Practices in Russia," Organizational Dynamics, 4, 1-12.

Geringer, M. and L. Hebert (1989), "Control and Performance of International Joint Ventures," Journal of International Business Studies, 20, 2, 235-254. 
William Davidson Institute Working Paper 598

Giddens, A. (1990), The Consequences of Modernity, Palo Alto: Stanford University Press.

Glaser, B. (1978), Theoretical Sensitivity, Mill Valley, CA: Sociology Press.

Goskomstat (1998), Goskomstat Registry of Foreign Firms for 1998, Moscow: Goskomstat.

Granrose, C.S. (1997), "Cross-Cultural Socialization of Asian Employees in U.S. Organizations," in C.S.Granrose and S. Oskamp, Cross-Cultural Work Groups, Thousands Oaks, CA: Sage Publications, 61-89.

Hall, E. (1976), Beyond Culture, Garden City, NJ: Doubleday Anchor.

Hamel, G. and C.K. Prahalad (1994), Competing for the Future, Boston, MA: Harvard Business School Press.

Hatch, M. J. (1993), “The Dynamics of Organizational Culture,” Academy of Management Review, $18,4,657-693$.

Hofstede, G. (1980a), “Motivation, Leadership, and Organization: Do American Theories Apply Abroad?" Organizational Dynamics, 9, 1, 42-58.

Hofstede, G. (1980b), Culture's Consequences, Newbury Park, CA.: Sage.

Hofstede, G. (1993), "Cultural Constraints in Management Theories," Academy of Management Executive, 7, 1, 81-94.

Holt, D. H., D.A. Ralston, and R.H. Terpstra (1994), “Constraints on Capitalism in Russia: The Management Psyche,” California Management Review, 36, 3, 124-136.

Kanter, R. (1983), The Change Masters: Innovation for Productivity in the American Corporation, New York: Simon and Schuster.

Katzenbach, R. (1993), The Wisdom of Teams: Creating the High-Performance Organization, Boston, MA: Harvard Business School Press.

Kets de Vries, M.F.R. (2000), “A Journey into the Wilde East: Leadership Style and Organizational Practices in Russia,” Organizational Dynamics, 28, 4, 67-81.

Kliuchevskii, V. O. (1990), Kluchevskii's Collected Works (in Russian), Moscow: Mysl.

Kotter, J.P. and J.L. Heskett (1992), Corporate Culture and Performance, New York: Free Press.

Kvint, V. (1994), “Don’t give up on Russia,” Harvard Business Review, March-April, 62-74.

Lammers, .J. and D.J. Hickson (1979), “Towards a Comparative Sociology of Organizations”, in C.J. Lammers and D.J. Hickson (Eds.), Organizations Alike and Unalike: International and Institutional Studies in Sociology of Organizations, London: Routledge and Kegan Paul. 
Lawler, E. E. III. (1996), From the Ground Up: Six Principles for Building the New Logic Corporation, San Francisco, CA: Jossey-Bass.

Lawrence, P.R. and C.A. Vlachoutsicos (1990), Behind Factory Walls: Decision Making in Soviet and U.S. Enterprises, Boston: Harvard Business School Press.

Lawrence, P.R. and C.A. Vlachoutsicos (1993), "Joint Ventures in Russia: Put the Locals in Charge," Harvard Business Review, January-February, 44-54.

Lee, C. and P. W. Beamish (1995), "The Characteristics of Performance of Korean Joint Ventures in LDCs," Journal of International Business Studies, 26: 637-654.

Likert, R. (1961), New Patterns of Management, New York: McGraw-Hill.

Luthans, F., D.H. Welsch, and S. Rosenkratz (1993), "What do Russian Managers Really Do? An Observational Study With Comparisons to U.S. Managers," Journal of International Business Studies, 24, 4, 741-761.

Martin, J. (1992), Cultures in Organizations: Three Perspectives, New York: Oxford University Press.

May, R., C. Bermann-Young, and D. Ledgerwood (1998), "Russian Human Resource Management," European Management Journal, 16, 4, 447-459.

Merton, R., Fisk, M., and P. Kendall (1963), The Focused Interview, New York: Free Press.

Mintzberg, H. (1994), The Rise and Fall of Strategic Planning: Reconciling for Planning, Plans, Planners, New York: Free Press.

Mintzberg, H. (1987), Crafting Strategy, Harvard Business Review, 65, 66-75.

Nadler, D. (1998), Champions of Change : How CEOs and Their Companies are Mastering the Skills of Radical Change, San Francisco, CA: Jossey-Bass.

Newman, K.L. and S.D. Nollen (1998), Managing Radical Organizational Change, Thousand Oaks, CA: Sage Publications.

O’Reilly, C.A., III. (1989), “Corporations, Culture, and Commitment: Motivation and Social Control in Organizations," California Management Review, 31, 4, 9-25.

Ohmae, K. (1982), The Mind of the Strategist: The Art of Japanese Business, New York: McGrawHill.

Peters, T.J. and R.H. Waterman (1982), In Search of Excellence Lessons from America's Best-Run Companies, New York: Harper \& Row.

Pfeffer, J. (1994), Competitive Advantage Through People: Unleashing the Power of the Work Force, Boston: Harvard Business Press. 
Powell, T. C. (1992), “Organizational Alignment as a Competitive Advantage,” Strategic Management Journal, 13, 119-134.

Puffer, S.M. (1992), The Russian Management Revolution: Preparing Managers for a Market Economy, Armonk, NY: ME Sharp.

Puffer, S. and S. Shekshnia (1996), "The fit between Russian culture and compensation, The International Executive, 38, 217-241.

Puffer, S.M. and D.J. McCarthy (1995), "Finding the Common Ground in Russian and American Business Ethics," California Management Review, 37, 2, 29-46.

Puffer, S. M, D.J. McCarthy, and A.V. Zhuplev (1998), "Doing Business in Russia: Lessons From Early Entrants," Thunderbird International Business Review, 40, 5, 461-484.

Puffer, S.M., D.J. McCarthy, and A.I. Naumov (1997), “Russian Managers' Beliefs About Work: Beyond the Stereotypes," Journal of World Business, 32, 258-276.

Ralston, D. A., D.H. Holt, R.H. Tepstra, and Y. Kai-Cheng (1997), “The Impact of National Culture and Economic Ideology on Managerial Work Values: A Study of the United States, Russia, Japan, and China," Journal of International Business Studies, 28, 1, 177-208.

Saffold, G. (1988), “Culture Traits, Strength, and Organizational Performance: Moving Beyond 'Strong' Culture,' Academy of Management Review, 13, 4, 546-558.

Schein, E. (1985), Organizational Culture and Leadership, San Francisco, CA: Jossey-Bass.

Schein, E. (1990), “Organizational Culture,” American Psychologist, 45, 109-119.

Senge, P. (1990), The Fifth Discipline: The Art and Practice of the Learning Organization, New York: Doubleday/Currency.

Shaw, J., J. Delery, D. Jenkins, and N. Gupta (1998), “An Organizational-Level Analysis of Voluntary and Involuntary Turnover," Academy of Management Journal, 41, 5, 511-525.

Shekshnia,S. (1998), “Western multinationals' human resource practices in Russia," European Management Journal, 16, 460-465.

Spreitzer, G. (1995), "Psychological Empowerment in the Workplace: Dimensions, Measurement, and Validation," Academy of Management Journal, 38, 1442-65.

Stalk, G. (1988), Competing Against Time: How Time-Based Competition is Reshaping Global Markets, New York: Free Press.

Trompenaars, F. (1998), (2ed.) Riding the Waves of Culture: Understanding Cultural Diversity in Global Business, New York: Irwin. 
Van Maanen, J. and S. Barley. (1984), “Occupational Communities: Culture and Control in Organizations," In B. Staw and L. Cummings (Eds.), Research in Organizational Behavior, Vol 6, 287- 366, Greenwich, CT: JAI Press.

Vlachoutsicos, C. (2001), "Russian Communitarism: An Invisible Fist in the Transformation Process of Russia," In D. Denison (Ed.), Managing Organizational Change in Transition Economies, Mahway, NJ: Lawrence Erlbaum Associates.

Vlachoutsicos, C. and P.L. Lawrence. (1990), "What we don't know about Soviet management," Harvard Business Review, November-December, 50-63.

Welsch, D., F. Luthans, and S. Sommer (1993), "Managing Russian Factory Workers: The Impact of US-Based Behavioral and Participative Techniques," Academy of Management Journal, $36,1,58-79$.

Wilkins, A. and W. G. Ouchi (19831), "Efficient Cultures: Exploring the Relationship Between Culture and Organizational Performance," Administrative Science Quarterly, 28, 468-481.

World Bank (2001), Country Statistics. World Bank. www.worldbank.org.

Yin, R.K. (1984), Case Study Research, London: Sage Publications. 


\section{Table 1}

\section{Factor Analysis of Organizational Culture Measures ${ }^{1}$}

\begin{tabular}{|c|c|c|c|c|}
\hline & Factor 1 & Factor 2 & Factor 3 & Factor 4 \\
\hline \multicolumn{5}{|l|}{ Involvement } \\
\hline Empowerment & .21 & .83 & .08 & .14 \\
\hline Team Orientation & .01 & .79 & .18 & .09 \\
\hline Capability Development & .10 & .75 & .12 & .31 \\
\hline \multicolumn{5}{|l|}{ Consistency } \\
\hline Core Values & .89 & .11 & .05 & .23 \\
\hline Agreement & .89 & .26 & .18 & .09 \\
\hline Coordination \& Integration & .83 & .17 & .24 & .26 \\
\hline \multicolumn{5}{|l|}{ Adaptability } \\
\hline Organizational Learning & .14 & .21 & .80 & .16 \\
\hline Customer Focus & .26 & .10 & .83 & .17 \\
\hline Creating Change & .16 & .07 & .80 & .36 \\
\hline \multicolumn{5}{|l|}{ Mission } \\
\hline Vision & .22 & .33 & .16 & .67 \\
\hline Goals and Objectives & .00 & .06 & .27 & .84 \\
\hline Strategic Directions & .00 & .29 & .14 & .78 \\
\hline Eigenvalue & 5.11 & 1.79 & 1.18 & 1.03 \\
\hline$\%$ Variance Explained & 42.60 & 14.91 & 9.79 & 8.55 \\
\hline Alpha (for bold items) & .81 & .89 & .86 & .76 \\
\hline
\end{tabular}


Table 2

Culture and Effectiveness Correlations

\begin{tabular}{|c|c|c|c|c|c|c|c|c|}
\hline & $\begin{array}{l}\text { Overall } \\
\text { Perform }\end{array}$ & $\begin{array}{l}\text { Market } \\
\text { Share }\end{array}$ & $\begin{array}{l}\text { Sales } \\
\text { Growth }\end{array}$ & Profits & $\begin{array}{l}\text { Employ } \\
\text { Satisfact. }\end{array}$ & Quality & $\begin{array}{l}\text { Product } \\
\text { Develop }\end{array}$ & $\begin{array}{l}\text { Effective } \\
\text { Index }\end{array}$ \\
\hline \multicolumn{9}{|l|}{ Russian Data } \\
\hline Involvement & $.44 * *$ & $.33 * *$ & $.38^{\star * * *}$ & $.37 * *$ & $.46 * *$ & $.42 * *$ & $.33 * *$ & $.48 * *$ \\
\hline Team Orientation & $.42 * *$ & $.28 * *$ & $.35 * *$ & $.34 * *$ & $.44 * *$ & $.41 * *$ & $.30 * *$ & $.45^{* *}$ \\
\hline Capability Devel. & $.38 * *$ & $.32 * *$ & $.33 * *$ & $.34 * *$ & $.35 * *$ & $.34 * *$ & $.32 * *$ & $.44 * *$ \\
\hline Empowerment & $.35 * *$ & $.25 * *$ & $.32 * *$ & $.27 * *$ & $.41 * *$ & $.35 * *$ & $.24 * *$ & $.36 * *$ \\
\hline Consistency & $.31 * *$ & $.22 * *$ & $.25 * *$ & $.28 * *$ & $.23 * *$ & $.27 * *$ & .12 & $.29 * *$ \\
\hline Core Values & $.30 * *$ & $.30 * *$ & $.22 * *$ & $.25 * *$ & $.21 * *$ & $.24 * *$ & .11 & $.28 * *$ \\
\hline Agreement & $.24 * *$ & $.17 *$ & $.24 * *$ & $.20 *$ & $.16^{*}$ & $.21 *$ & .07 & $.21 * *$ \\
\hline Integration & $.29 * *$ & $.20 *$ & $.22 * *$ & $.29 * *$ & $.25 * *$ & $.27 * *$ & .13 & $.30 * *$ \\
\hline Adaptability & $.46 * *$ & $.30 * *$ & $.27 * *$ & $.45 * *$ & $.33 * *$ & $.31 * *$ & $.36 * *$ & $.54 * *$ \\
\hline Org.Learning & $.40 * *$ & $.30 * *$ & $.24 * *$ & $.39 * *$ & $.28 * *$ & $.26 * *$ & $.33 * *$ & $.49 * *$ \\
\hline Customer Focus & $.39 * *$ & $.16^{*}$ & $.24 * *$ & $.40 * *$ & $.29 * *$ & $.24 * *$ & $.31 * *$ & $.47 * *$ \\
\hline Creating Change & $.35 * *$ & $.32 * *$ & $.22 * *$ & $.36 * *$ & $.28 * *$ & $.28 * *$ & $.28 * *$ & $.42 * *$ \\
\hline Mission & $.20 * *$ & $.30 * *$ & $.45 * *$ & $.26 * *$ & $.38 * *$ & $.37 * *$ & $.27 * *$ & $.39 * *$ \\
\hline Vision & .07 & .10 & $.33 * *$ & .13 & $.18 *$ & $.19 *$ & .13 & $.38 * *$ \\
\hline Goals & $.19 *$ & $.30 * *$ & $.31 * *$ & $.19 *$ & $.34 * *$ & $.33 * *$ & $.23 * *$ & $.27 * *$ \\
\hline Strategy & $.26 * *$ & $.38 * *$ & $.48 * *$ & $.34 * *$ & $.45 * *$ & $.41 * *$ & $.33 * *$ & $.40 * *$ \\
\hline \multicolumn{9}{|l|}{ US Data } \\
\hline Involvement & $.55 * *$ & .14 & $.26 * *$ & $.22 *$ & $.73 * *$ & $.54 * *$ & $.42 * *$ & $.42 * *$ \\
\hline Team Orientation & $.50 * *$ & .07 & $.22 *$ & $.20 *$ & $.66 * *$ & $.49 * *$ & $.34 * *$ & $.32 * *$ \\
\hline Capability Devel. & $.55 * *$ & $.27 * *$ & $.32 * *$ & $.26 * *$ & $.70 * *$ & $.55 * *$ & $.46 * *$ & $.43 * *$ \\
\hline Empowerment & $.50 * *$ & .09 & $.21 *$ & $.17^{*}$ & $.71 * *$ & $.47 * *$ & $.40 * *$ & $.35 * *$ \\
\hline Consistency & $.55 * *$ & $.19 *$ & $.26 * *$ & $.28 * *$ & $.70 * *$ & $.58 * *$ & $.37 * *$ & $.31 * *$ \\
\hline Core Values & $.53 * *$ & $.22 *$ & $.26 * *$ & $.27 * *$ & $.69 * *$ & $.53 * *$ & $.32 * *$ & $.27 * *$ \\
\hline Agreement & $.49 * *$ & $.21 *$ & $.25 * *$ & $.28 * *$ & $.58 * *$ & $.51 * *$ & $.34 * *$ & $.34 * *$ \\
\hline Integration & $.49 * *$ & .09 & $.20 *$ & $.20 *$ & $.64 * *$ & $.54 * *$ & $.40 * *$ & $.49 * *$ \\
\hline Adaptability & $.51 * *$ & .14 & $.26 * *$ & .16 & $.65 * *$ & $.50 * *$ & $.45 * *$ & $.35 * *$ \\
\hline Org.Learning & $.45^{* *}$ & .04 & $.20 *$ & .13 & $.65 * *$ & $.44 * *$ & $.34 * *$ & $.33 * *$ \\
\hline Customer Focus & $.43 * *$ & .14 & $.19 *$ & .09 & $.53 * *$ & $.47 * *$ & $.35 * *$ & $.19 * *$ \\
\hline Creating Change & $.48 * *$ & $.18 *$ & $.29 * *$ & $.22 *$ & $.56 * *$ & $.44 * *$ & $.51 * *$ & $.38 * *$ \\
\hline Mission & $.58 * *$ & $.26 * *$ & $.38 * *$ & $.33 * *$ & $.68 * *$ & $.51 * *$ & $.43 * *$ & $.46 * *$ \\
\hline Vision & $.57 * *$ & $.18 *$ & $.34 * *$ & $.27 * *$ & $.73 * *$ & $.56 * *$ & $.44 * *$ & $.45 * *$ \\
\hline Goals & $.50 * *$ & $.22 *$ & $.33 * *$ & $.35 * *$ & $.56 * *$ & $.40 * *$ & $.33 * *$ & $.33 * *$ \\
\hline Strategy & $.57 * *$ & $.34 * *$ & $.39 * *$ & $.33^{* *}$ & $.61 * *$ & $.47 * *$ & $.44 * *$ & $.49 * *$ \\
\hline
\end{tabular}


Table 3

Regressions of Effectiveness on Organizational Culture Dimensions: Russian Data ${ }^{1}$

\begin{tabular}{|c|c|c|c|c|c|c|c|c|}
\hline \multirow{2}{*}{$\begin{array}{l}\text { Independent } \\
\text { Variable }\end{array}$} & \multicolumn{8}{|c|}{ Dependent Variables } \\
\hline & $\begin{array}{l}\text { Overall } \\
\text { Performance }\end{array}$ & $\begin{array}{l}\text { Market } \\
\text { Share }\end{array}$ & $\begin{array}{l}\text { Sales } \\
\text { Growth }\end{array}$ & Profitability & $\begin{array}{l}\text { Employee } \\
\text { Satisfaction }\end{array}$ & Quality & $\begin{array}{l}\text { Product_- } \\
\text { Development }\end{array}$ & $\begin{array}{l}\text { Effectiveness } \\
\text { index }\end{array}$ \\
\hline Involvement & $.27 * * *$ & $.20 *$ & $.21 *$ & $.18 *$ & $.33 * * * *$ & $.29 * * * *$ & $.18 *$ & $.26 * * *$ \\
\hline Consistency & .13 & .05 & .13 & .07 & .05 & .12 & -.06 & .05 \\
\hline Adaptability & $.30 * * * *$ & .09 & .05 & $.31 * * * *$ & .02 & .00 & $.26 * * *$ & $.34 * * * *$ \\
\hline Mission & .09 & .10 & $.36 * * * *$ & -.01 & $.22 * *$ & $.21 * *$ & .08 & .06 \\
\hline Firm Size & .08 & .14 & .06 & .11 & .10 & $.18 * *$ & .02 & .12 \\
\hline$\%$ Manufacturing & -.03 & -.05 & -.05 & -.11 & -.11 & -.13 & -.02 & -.04 \\
\hline Firm Age & .08 & .12 & .01 & .07 & .05 & .00 & .07 & -.07 \\
\hline Industry $1^{2,3}$ & -.03 & -.10 & -.03 & $-.17 *$ & -.09 & -.14 & -.03 & -.10 \\
\hline Industry $2^{2,3}$ & .06 & .04 & .04 & -.05 & .02 & .07 & 11 & -.05 \\
\hline Industry $3^{2,3}$ & .09 & -.06 & .01 & .00 & -.00 & .02 & -.08 & -.06 \\
\hline Industry $4^{2,3}$ & -.01 & -.06 & .09 & -.01 & -.10 & .01 & -.03 & -.02 \\
\hline Industry $5^{2,3}$ & .08 & -.10 & .03 & -.10 & .02 & .02 & -.01 & -.08 \\
\hline $\begin{array}{l}\text { Home country } \\
\text { Canada }^{3}\end{array}$ & .10 & -.08 & -.05 & -.02 & .03 & .05 & .01 & -.08 \\
\hline Finland $^{3}$ & .09 & -.12 & .09 & -.08 & .08 & -.01 & -.01 & -.08 \\
\hline Germany $^{3}$ & .01 & -.15 & .02 & -.09 & -.11 & -.08 & .05 & -.02 \\
\hline Sweden $^{3}$ & .04 & .02 & -.03 & .03 & .00 & .02 & .08 & -.02 \\
\hline $\mathrm{USA}^{3}$ & .05 & -.13 & -.02 & -.08 & -.00 & -.05 & -.07 & -.01 \\
\hline $\begin{array}{l}\text { Manager } \\
\text { US/Russian }\end{array}$ & .06 & -.09 & .13 & .01 & .05 & .03 & .01 & .05 \\
\hline $\mathrm{F}$ full model & $4.27 * * * *$ & $2.72 * * * *$ & $4.08 * * * *$ & $4.32 * * * *$ & $4.14 * * * *$ & $4.10 * * * *$ & $2.39 * * * *$ & $6.18 * * * *$ \\
\hline Full model $\mathrm{R}^{2}$ & .32 & .23 & .31 & .33 & .32 & .32 & .21 & .41 \\
\hline Adjusted $\mathrm{R}^{2}$ & .25 & .15 & .24 & .25 & .24 & .24 & .12 & .34 \\
\hline$\Delta$ adjusted $\mathrm{R}^{24}$ & .24 & .10 & .23 & .20 & .23 & .21 & .10 & .33 \\
\hline $\mathrm{F}$ for $\Delta$ adjusted $\mathrm{R}^{2}$ & $12.44 * * * *$ & $4.87 * * * *$ & $12.05 * * * *$ & $10.49 * * * *$ & $12.30 * * * *$ & $11.20 * * * *$ & $4.62 * * * *$ & $20.15 * * * *$ \\
\hline DF & 160 & 160 & 160 & 160 & 160 & 160 & 160 & 160 \\
\hline
\end{tabular}

$* * * * \rho<.001, * * * \rho<.005, * * \rho<.01, * \rho<.05$

1. $\mathrm{N}=179$; standardized regression coefficients (Betas) are reported.

2. Industry $1=$ electrical, industrial, and precision instrument manufacturing; Industry $2=$ wood, paper, textiles, food, and metal manufacturing; Industry $3=$ other manufacturing; Industry 4=banking, insurance, real estate, advertising, and accounting; Industry 5=wholesale and retail trade.

3. Industry 6= "other services" and home country "France" are excluded from the regressions so that the model is not over-determined.

4. " $\Delta$ adjusted $\mathrm{R}^{2 "}$ " shows the amount of additional variance explained by adding the four organizational culture variables as a set to regressions including all 14 control variables. 
Table 4

Regressions of Effectiveness on Organizational Culture Dimensions: USA Data ${ }^{1,2}$

\begin{tabular}{|c|c|c|c|c|c|c|c|c|}
\hline \multirow{2}{*}{$\begin{array}{l}\text { Independent } \\
\text { Variable }\end{array}$} & \multicolumn{8}{|c|}{ Dependent Variables } \\
\hline & $\begin{array}{l}\text { Overall } \\
\text { Perform }\end{array}$ & $\begin{array}{l}\text { Market } \\
\text { Share }\end{array}$ & $\begin{array}{l}\text { Sales } \\
\text { Growth }\end{array}$ & Profitability & $\begin{array}{l}\text { Employee } \\
\text { Satisfaction }\end{array}$ & Quality & $\begin{array}{l}\text { Product } \\
\text { Development }\end{array}$ & $\begin{array}{l}\text { Effectiveness } \\
\text { Index }\end{array}$ \\
\hline Involvement & 0.21 & -0.18 & -0.10 & -0.01 & $0.52 * * * *$ & 0.13 & 0.06 & $0.35 * * *$ \\
\hline Consistency & 0.10 & 0.07 & -0.13 & 0.21 & 0.19 & $0.45 * *$ & -0.13 & -0.13 \\
\hline Adaptability & -0.06 & -0.13 & -0.01 & $-0.38 *$ & -0.11 & -0.02 & 0.32 & -0.21 \\
\hline Mission & $0.38 * *$ & $0.46^{* *}$ & $0.58 * * * *$ & $0.47 * * *$ & 0.17 & 0.04 & 0.24 & $0.48 * * * *$ \\
\hline $\mathrm{F}$ & $18.09 * * * *$ & $3.13 *$ & $5.90 * * * *$ & $5.64 * * * *$ & $41.44 * * * *$ & $16.36 * * * *$ & $9.21 * * * *$ & $13.44 * * * *$ \\
\hline $\mathrm{R}^{2}$ & 0.36 & 0.09 & 0.16 & 0.15 & 0.56 & 0.34 & 0.22 & 0.26 \\
\hline Adjusted $\mathrm{R}^{2}$ & 0.34 & 0.06 & 0.13 & 0.12 & 0.55 & 0.318 & 0.20 & 0.24 \\
\hline DF & 90 & 90 & 90 & 90 & 90 & 90 & 90 & 90 \\
\hline
\end{tabular}

$* * * * \rho<.001, * * * \rho<.005, * * \rho<.01, * \rho<.05$

1. Standardized regression coefficients (Betas) are reported above.

2. $\mathrm{N}=94$ 
Table 5

Ratings of Culture Traits and Effectiveness for Case Study Firms

Involvement Consistency Adaptability \begin{tabular}{ccc} 
Overall & $\begin{array}{c}\text { Effectiveness } \\
\text { Index }\end{array}$ \\
\hline
\end{tabular}

AGA: Industrial Gases

$\begin{array}{lllllll}\text { Researcher } & \text { Low } & \text { Low } & \text { Low } & \text { Low } & \text { Low } & \text { Low } \\ \text { GM } & 2.3 & 2.7 & 2.0 & 2.7 & 2.3 & 2.2 \\ \text { Average 10 } & 2.6 & 2.0 & 2.7 & 2.0 & 2.0 & 2.0\end{array}$

Respondents

Lift: Elevators

Researcher Low

GM $\quad 2.7$

Average $10 \quad 2.4$

4.3

High

4.3

4.0

Medium

Medium Low

Low

3.3

3.0

2.7

2.7

Respondents

3.6

$3.1 \quad 2.5$

2.4

Alfa Laval: Heat Exchangers

$\begin{array}{lllllll}\text { Researcher } & \text { High } & \text { Low } & \text { High } & \text { Medium } & \text { Medium } & \text { Medium } \\ \text { GM } & 4.0 & 2.7 & 4.3 & 3.3 & 3.7 & 3.8 \\ \text { Average 10 } & 3.7 & 2.9 & 4.0 & 3.2 & 3.5 & 3.9 \\ \text { Respondents } & & & & & & \end{array}$

Respondents

AssiDoman: Cardboard Boxes

$\begin{array}{lllllll}\text { Researcher } & \text { Medium } & \text { Medium } & \text { High } & \text { High } & \text { High } & \text { High } \\ \text { GM } & 3.7 & 3.7 & 4.3 & 4.7 & 4.7 & 4.6 \\ \text { Average 10 } & 3.3 & 3.5 & 4.5 & 4.3 & 4.4 & 4.4 \\ \text { respondents } & & & & & & \end{array}$


William Davidson Institute Working Paper 598

Figure 1

Model of Organizational Culture

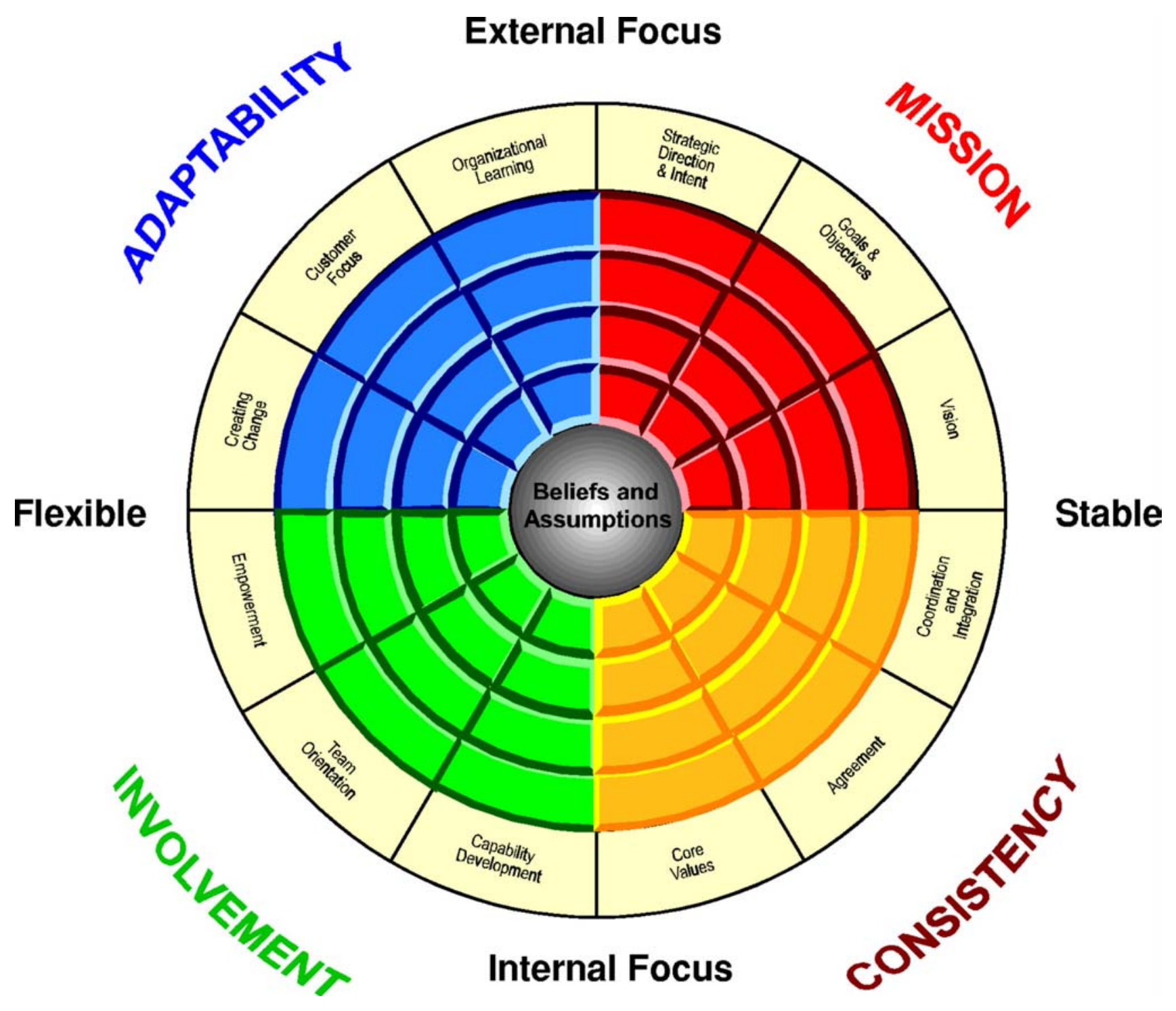


Figure 2

\section{Cultural Dynamics of Firms in Russia}

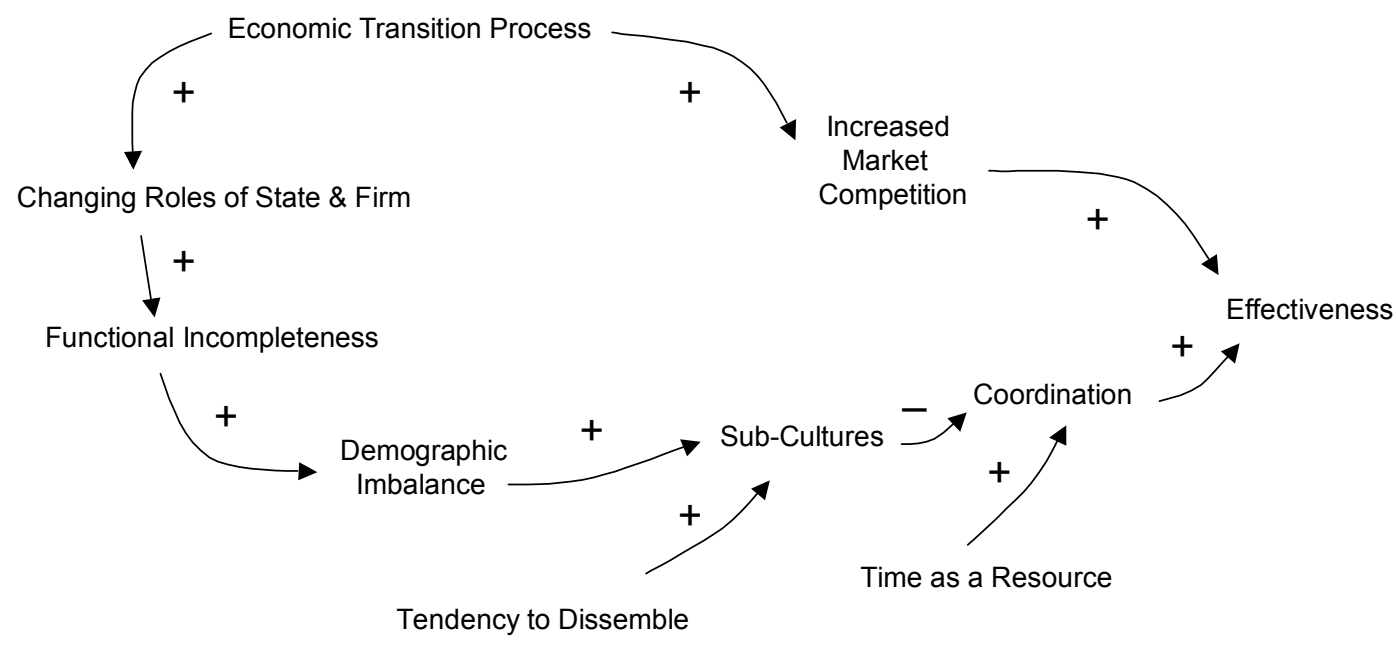




\section{Appendix A \\ Items and Indexes for Each Trait}

\begin{tabular}{|c|c|c|}
\hline Index & Scale & Item \\
\hline \multirow[t]{3}{*}{ Involvement } & Empowerment & $\begin{array}{l}\text { 1. Decisions are usually made at the level where the best information is } \\
\text { available. } \\
\text { 2. Information is widely shared so that everyone can get the information he or } \\
\text { she needs when it's needed. } \\
\text { 3. Everyone believes that he or she can have a positive impact. }\end{array}$ \\
\hline & Team Orientation & $\begin{array}{l}\text { 4. Working in this organization is like being part of a team. } \\
\text { 5. This organization relies on horizontal control and coordination to get work } \\
\text { done, rather than hierarchy. } \\
\text { 6. Teams are the primary building blocks of this organization. }\end{array}$ \\
\hline & $\begin{array}{l}\text { Capability } \\
\text { Development }\end{array}$ & $\begin{array}{l}\text { 7. This organization is constantly improving compared with its competitors in } \\
\text { many dimensions. } \\
\text { 8. This organization continuous invests in the skills of employees. } \\
\text { 9. The capability of people in this organization is viewed as an important } \\
\text { source of competitive advantage. }\end{array}$ \\
\hline \multirow[t]{3}{*}{ Consistency } & Core Values & $\begin{array}{l}\text { 10. The leaders and managers follow the guidelines that they set for the rest of } \\
\text { the organization. } \\
\text { 11. There is a clear and consistent set of values in this organization that governs } \\
\text { the way we do business. } \\
\text { 12. This organization has an ethical code that guides our behavior and tells us } \\
\text { right from wrong. }\end{array}$ \\
\hline & Agreement & $\begin{array}{l}\text { 13. When disagreements occur, we work hard to achieve solutions that benefit } \\
\text { both parties in the disagreement. } \\
\text { 14. It is easy to reach consensus, even on difficult issues. } \\
\text { 15. We often have trouble reaching agreement on key issues. }{ }^{*}\end{array}$ \\
\hline & $\begin{array}{l}\text { Coordination \& } \\
\text { Integration }\end{array}$ & $\begin{array}{l}\text { 16. People from different organizational units still share a common perspective. } \\
\text { 17. It is easy to coordinate projects across functional units in this organization. } \\
\text { 18. There is good alignment of goals across levels of this organization. }\end{array}$ \\
\hline \multirow[t]{3}{*}{ Adaptability } & Creating Change & $\begin{array}{l}\text { 19. This organization is very responsive and changes easily. } \\
\text { 20. This organization responds well to competitors and other changes in the } \\
\text { business environment. } \\
\text { 21. This organization continually adopts new and improved ways to do work. }\end{array}$ \\
\hline & Customer Focus & $\begin{array}{l}\text { 22. Customer comments and recommendations often lead to changes in this } \\
\text { organization. } \\
\text { 23. Customer input directly influences our decisions. } \\
\text { 24. The interests of the final customer often get ignored in our decisions. * }\end{array}$ \\
\hline & $\begin{array}{l}\text { Organizational } \\
\text { Learning }\end{array}$ & $\begin{array}{l}\text { 25. We view failure as an opportunity for learning and improvement. } \\
\text { 26. This organization encourages and rewards those who take risk. } \\
\text { 27. We make certain that we coordinate our actions and efforts between } \\
\text { different units in this organization. }\end{array}$ \\
\hline \multirow[t]{3}{*}{ Mission } & $\begin{array}{l}\text { Strategic } \\
\text { Direction } \\
\& \text { Intent }\end{array}$ & $\begin{array}{l}\text { 28. This organization has long-term purpose and direction. } \\
\text { 29. This organization has a clear mission that gives meaning and direction to } \\
\text { our work. } \\
\text { 30. This organization has a clear strategy for the future. }\end{array}$ \\
\hline & $\begin{array}{l}\text { Goals \& } \\
\text { Objectives }\end{array}$ & $\begin{array}{l}\text { 31. There is widespread agreement about goals of this organization. } \\
\text { 32. Leaders of this organization set goals that are ambitious, but realistic. } \\
\text { 33. The leadership has clearly stated the objectives we are trying to meet. }\end{array}$ \\
\hline & Vision & $\begin{array}{l}\text { 34. We have a shared vision of what this organization will be like in the future } \\
\text { 35. Leaders of this organization have a long-term orientation. } \\
\text { 36. Our vision creates excitement and motivation for our employees. }\end{array}$ \\
\hline
\end{tabular}

*Items in italics are worded negatively in the survey. Responses are reversed for analytic purposes. 


\section{Appendix B \\ Correlations for Russian Data ${ }^{1}$}

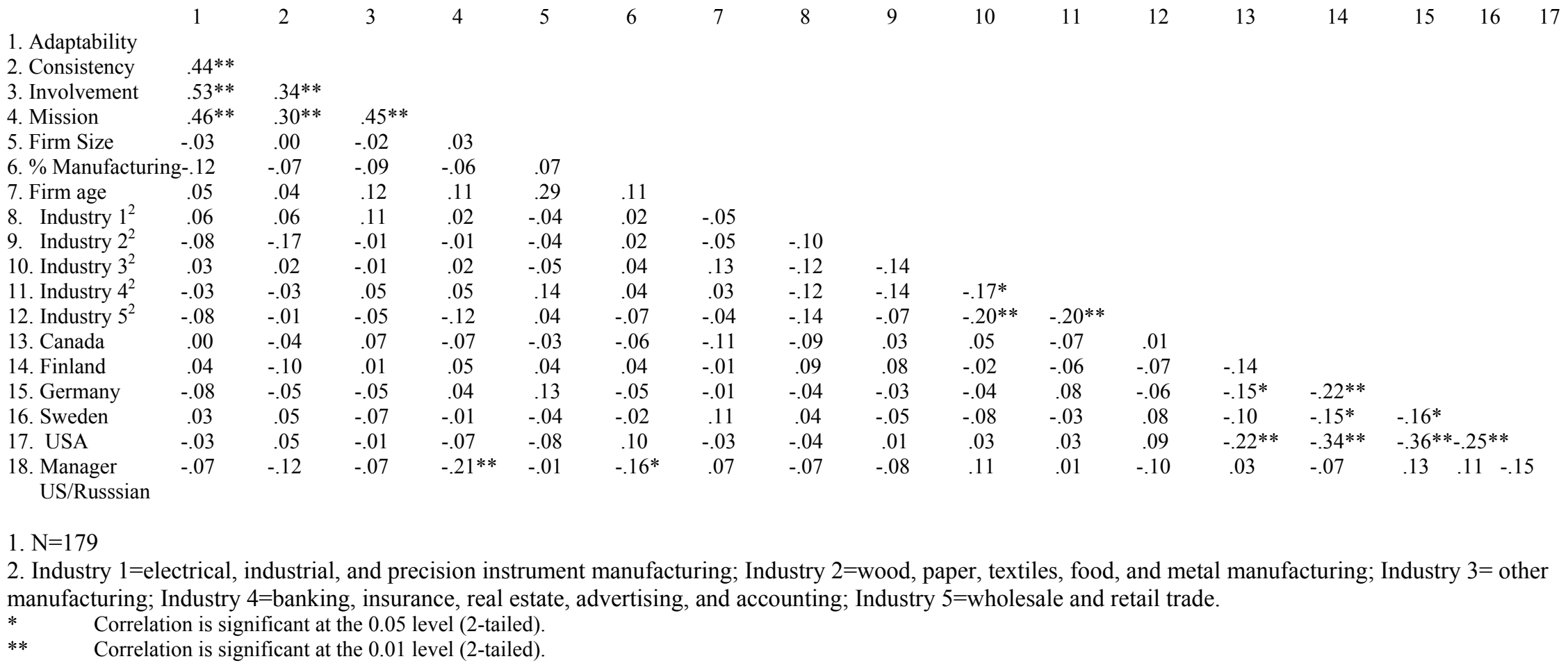




\section{DAVIDSON INSTITUTE WORKING PAPER SERIES - Most Recent Papers}

The entire Working Paper Series may be downloaded free of charge at: www.wdi.bus.umich.edu

CURRENT AS OF $7 / 29 / 03$

\begin{tabular}{|c|c|c|}
\hline Publication & Authors & Date \\
\hline $\begin{array}{l}\text { No. 598: Organizational Culture and Effectiveness: } \\
\text { Can American Theory Be Applied in Russia? }\end{array}$ & $\begin{array}{l}\text { Carl F. Fey and Daniel R. } \\
\text { Denison }\end{array}$ & July 2003 \\
\hline $\begin{array}{l}\text { No. 597: Asymmetric Fluctuation Bands in ERM and ERM-II: } \\
\text { Lessons from the Past and Future Challenges for EU Acceding } \\
\text { Countries }\end{array}$ & $\begin{array}{l}\text { Balázs Égert and Rafal } \\
\text { Kierzenkowski }\end{array}$ & July 2003 \\
\hline $\begin{array}{l}\text { No. 596: Mass Privatisation, Corporate Governance and Endogenous } \\
\text { Ownership Structure }\end{array}$ & Irena Grosfeld & July 2003 \\
\hline No. 595: WTO Accession: What's in it for Russia? & Abdur Chowdhury & July 2003 \\
\hline No. 594: The Political-Economy of Argentina's Debacle & Marcos A. Buscaglia & July 2003 \\
\hline $\begin{array}{l}\text { No. 593: While Labour Hoarding May Be Over, Insiders' Control Is } \\
\text { Not. Determinants of Employment Growth in Polish Large Firms, } \\
\text { 1996-2001 }\end{array}$ & $\begin{array}{l}\text { Kate Bishop and Tomasz } \\
\text { Mickiewicz }\end{array}$ & July 2003 \\
\hline $\begin{array}{l}\text { No. 592: Globalization and Trust: Theory and Evidence from } \\
\text { Cooperatives }\end{array}$ & $\begin{array}{l}\text { Ramon Casadesus-Masanell and } \\
\text { Tarun Khanna }\end{array}$ & June 2003 \\
\hline $\begin{array}{l}\text { No. 591: Restructuring or Disintegration of the German Corporate } \\
\text { Network: Globalization as a Fifth Column }\end{array}$ & Bruce Kogut and Gordon Walker & June 2003 \\
\hline $\begin{array}{l}\text { No. 590: Institutional Change and Firm Creation in East-Central } \\
\text { Europe: An Embedded Politics Approach }\end{array}$ & Gerald A. McDermott & June 2003 \\
\hline $\begin{array}{l}\text { No. 589: Legitimacy, Interest Group Pressure and Institutional Change: } \\
\text { The Case of Foreign Investment and Host Country Governments }\end{array}$ & $\begin{array}{l}\text { Witold J. Henisz and Bennet A. } \\
\text { Zelner }\end{array}$ & June 2003 \\
\hline $\begin{array}{l}\text { No. 588: Institutions and the Vicious Circle of Distrust in the Russian } \\
\text { Household Deposit Market, 1992-1999 }\end{array}$ & Andrew Spicer and William Pyle & June 2003 \\
\hline $\begin{array}{l}\text { No. 587: Foreign Direct Investment and the Business Environment in } \\
\text { Developing Countries: the Impact of Bilateral Investment Treaties }\end{array}$ & $\begin{array}{l}\text { Jennifer Tobin and Susan Rose- } \\
\text { Ackerman }\end{array}$ & June 2003 \\
\hline No. 586: Trust in China: A Cross-Regional Analysis & Rongzhu Ke and Weiying Zhang & June 2003 \\
\hline No. 585: Family Control and the Rent-Seeking Society & $\begin{array}{l}\text { Randall Morck and Bernard } \\
\text { Yeung }\end{array}$ & June 2003 \\
\hline $\begin{array}{l}\text { No. 584: Wage Determination: Privatised, New Private and State } \\
\text { Owned Companies, Empirical Evidence from Panel Data }\end{array}$ & $\begin{array}{l}\text { Tomasz Mickiewicz and Kate } \\
\text { Bishop }\end{array}$ & June 2003 \\
\hline No. 583: An Investigation of Firm-Level R\&D Capabilities in East Asia & $\begin{array}{l}\text { Gary H. Jefferson and Zhong } \\
\text { Kaifeng }\end{array}$ & June 2003 \\
\hline $\begin{array}{l}\text { No. 582: R\&D and Technology Transfer: Firm Level Evidence From } \\
\text { Chinese Industry }\end{array}$ & $\begin{array}{l}\text { Albert G.Z. Hu, Gary H. } \\
\text { Jefferson, Guan Xiaojing and } \\
\text { Qian Jinchang }\end{array}$ & June 2003 \\
\hline $\begin{array}{l}\text { No. 581: Credit Market Disequilibrium in Poland: Can We Find } \\
\text { What We Expect? Non-Stationarity and the "Min" } \\
\text { Condition }\end{array}$ & $\begin{array}{l}\text { Christophe Hurlin†and Rafal } \\
\text { Kierzenkowski }\end{array}$ & June 2003 \\
\hline $\begin{array}{l}\text { No. 580: Does it Take a Lula to go to Davos? } \\
\text { A Brief Overview of Brazilian Reforms, 1980-2000 }\end{array}$ & $\begin{array}{l}\text { Nauro F. Campos, Armando } \\
\text { Castellar Pinheiro, Fabio } \\
\text { Giambiagi and Maurício M. } \\
\text { Moreira }\end{array}$ & June 2003 \\
\hline $\begin{array}{l}\text { No. 579: Ceaseless Toil? Health and Labor Supply of the Elderly in } \\
\text { Rural China }\end{array}$ & $\begin{array}{l}\text { Dwayne Benjamin, Loren Brandt } \\
\text { and Jia-Zhueng Fan }\end{array}$ & June 2003 \\
\hline $\begin{array}{l}\text { No. 578: Shadow Economy, Rent-Seeking Activities and the Perils of } \\
\text { Reinforcement of the Rule of Law }\end{array}$ & Ekaterina Vostroknutova & June 2003 \\
\hline $\begin{array}{l}\text { No. 577: No Pain, No Gain: Market Reform, Unemployment, and } \\
\text { Politics in Bulgaria }\end{array}$ & Neven Valev & June 2003 \\
\hline $\begin{array}{l}\text { No. 576: Power Analysis of the Nice Treaty On the Future of European } \\
\text { Integration }\end{array}$ & Yener Kandogan & June 2003 \\
\hline $\begin{array}{l}\text { No. 575: Democracy's Spread: Elections and Sovereign Debt in } \\
\text { Developing Countries }\end{array}$ & $\begin{array}{l}\text { Steven A. Block, Burkhard N. } \\
\text { Schrage, and Paul M. Vaaler }\end{array}$ & June 2003 \\
\hline $\begin{array}{l}\text { No. 574: Reintroducing Intergenerational Equilibrium: Key Concepts } \\
\text { Behind the New Polish Pension System }\end{array}$ & Marek Góra & June 2003 \\
\hline
\end{tabular}

